\title{
أثر التعريف والتنكير في دلالة الجاز القرآني
}

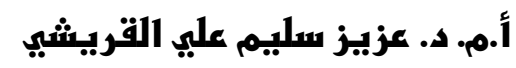

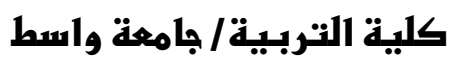

الاقدمهة:

قبل الولوج في ماهية البحث فلابد من التركيز على إن البحث المقدم يقوم على استشفاف الدلالة القائمـة من الامتزاج النحوي البلاغي, والأثر النحوي الدلالي الذي يقع على باب المجاز القرآني, ذلك التنزيل المقس الذي حارت ببيانه العقول , و هو خير الكلام, وأحسنه وأبلغه، وكما هو معروف: فإن عزل النص عن السياق العام قد

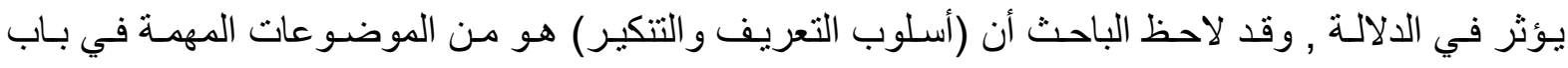
التر اكيب النحوية وكذلك (المجاز), بيد أنه قد لاحظ علاقة وثثقة بين المجاز و التعريف و التتكير , علاقة لاتكاد تنفصل عر اها, فما من نص مجازي، إلا وقد تخلله جزء من ذلك وبعد التوكل على الله ومر اجعة لآيـات المجاز القرآني وجد الباحث: أن التتكير والتعريف كان له الأثر الفاعل في رفهد الدلالـة المجازيـة أو إبانتها, أو تشكيل

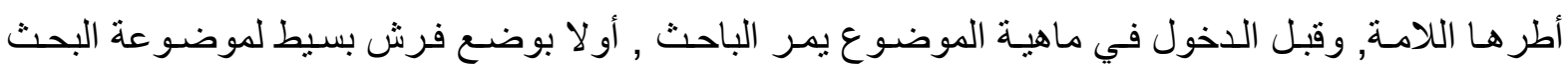

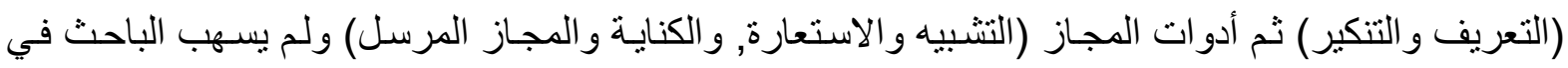
تقديم المهاد النظري, فهو مبسوط في كتب النحو والبلاغة, و إنما جعل الركب حول انبلاجـات الدلالة التي يشع ولـع منها التمازج الأسلوبي بين ( التعريف و التنكير والمجاز القرآني).

\section{التعريف والتنكير (ههاد نظري):}

وهو: من الأسـاليب التي لها قيمة كبيرة وهو من مباحث النحو التركيبية التي تتـاخل مـع البلاغـة

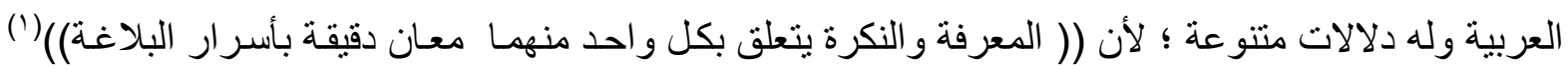

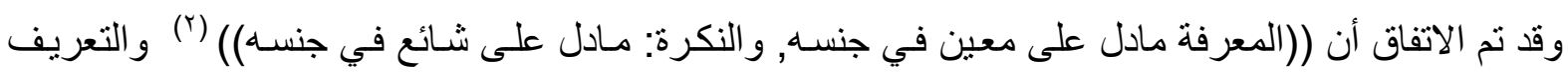

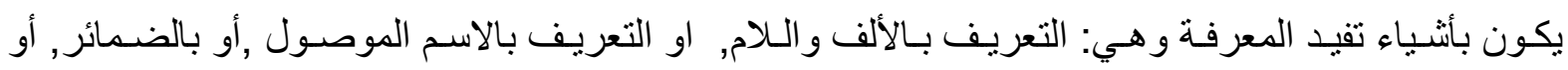

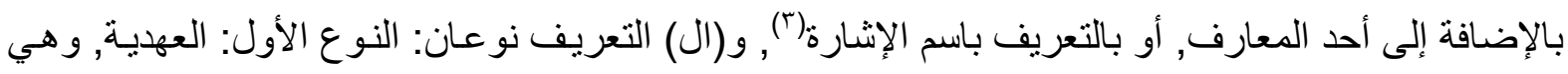
تللك التي تكون بين المتكلم والمخاطب في أمر معهود, و النوع الثاني: التي تفيد الجنس(ع) وأمـا (أل الجنس) فهي: تعطي دلالة الجنس المحض من غير إفادة للعهد(0) و المعنى الذي فيها (( يستقصي جميع أفر اد الجنس)) (آ) والنوع الآخر التعريف( باسم الإشـارة) وهو الإيمـاء الذي يثـار بـه إلى المسـى ذهنـا أو حضـورا بـالعين

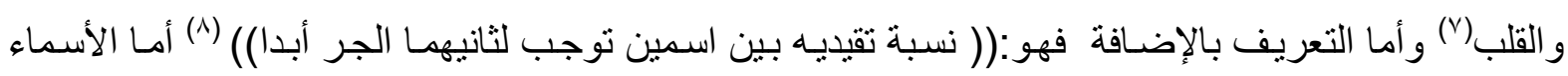

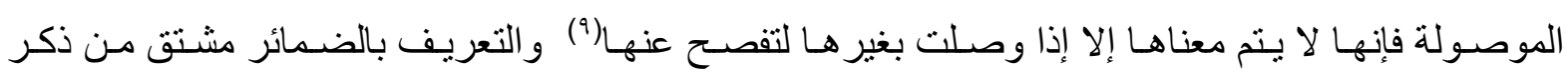
الضمير الدال على المعرفة فهو قد وضع لغائب أو متكلم أو حاضر معنى أو لفظا أو حكما (·').

أما التنكير: فهو الموضوع المقابل للتعريف في بابه, و النكرة: هي الثـيء الذي يخالف التعريف في

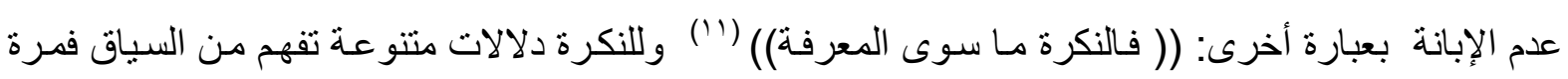
تعظيم وأخرى تحقير أو تكثير أو تقليل بحسب السياق الذي جاءت معسه (rا) و الذي يبرز النكرة من المعرفة 


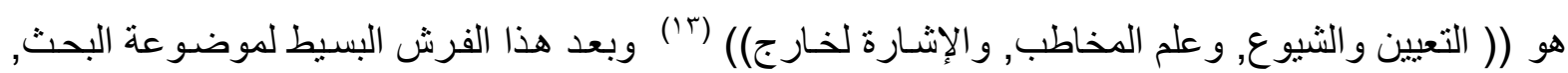

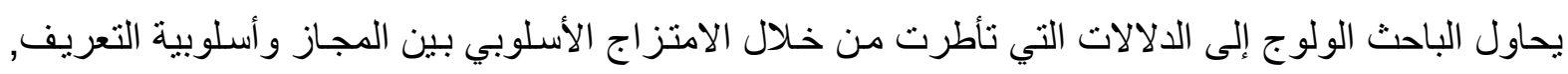

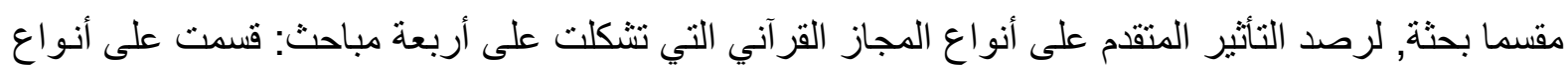

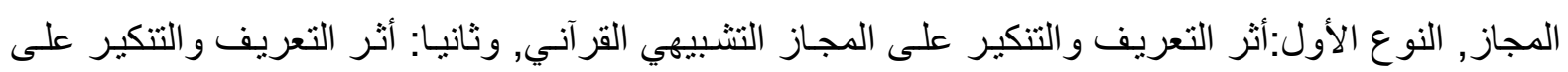

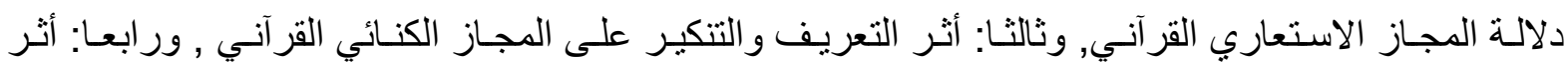

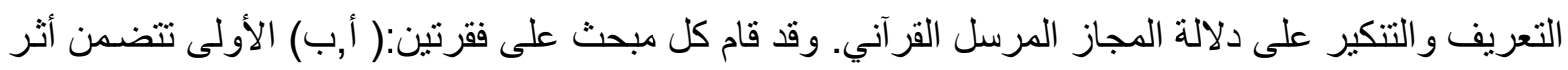
التعريف على المجاز والثنانية تتضمن أثنر التنكير عليه.

\section{أولا: أثر التعريف والتنكير على الجاز التشبيهي}

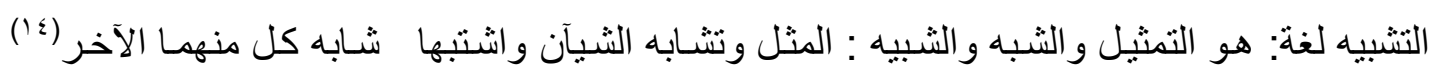

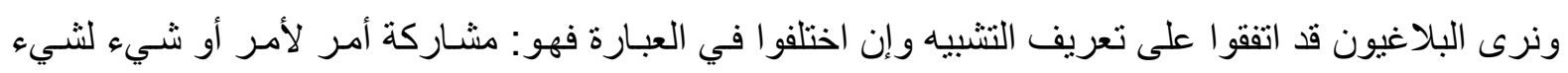

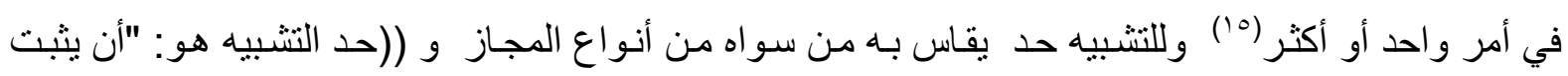

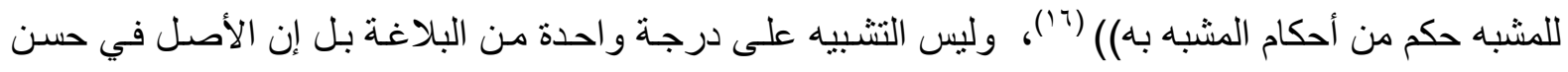

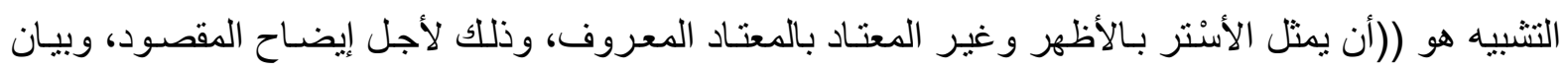

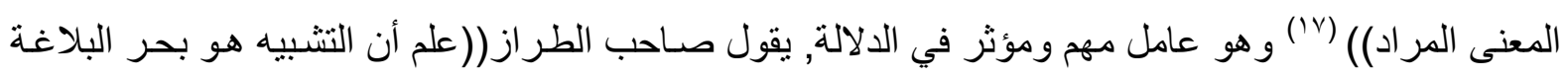

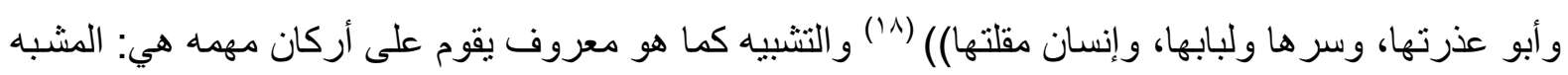

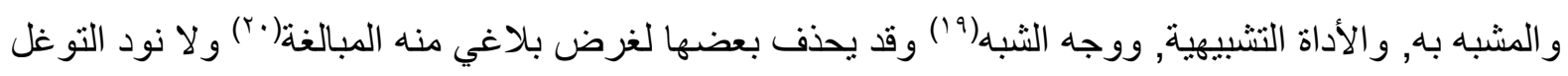

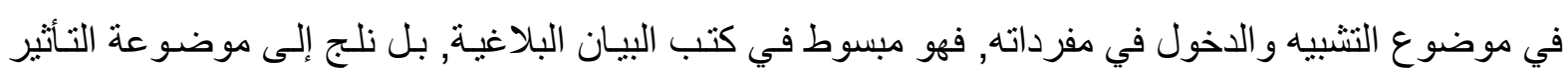
الدلالي للتعريف والتنكير في آليات الدجاز التشبيهي.

أــ أثر التعريف على المجاز التثبيهي: ويأتي التعريف مع التثبيه ليدل على حالة من المماتلـة والتقريب التي

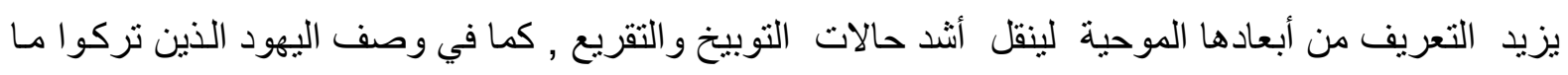

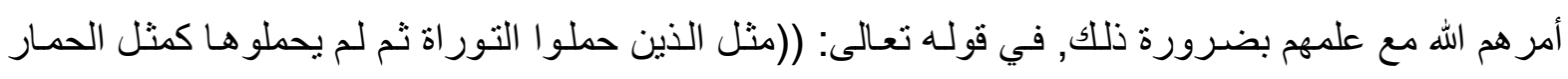

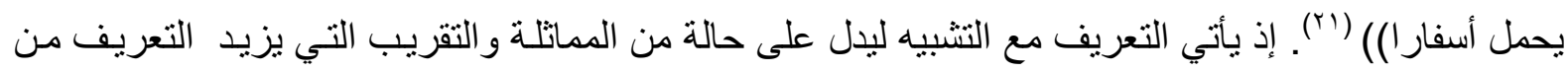

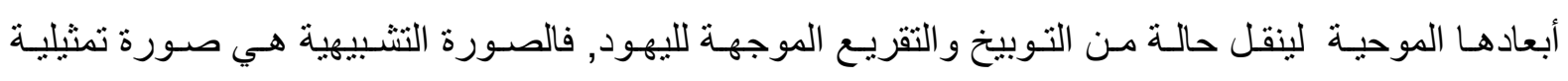

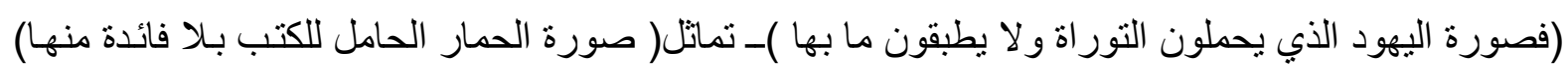

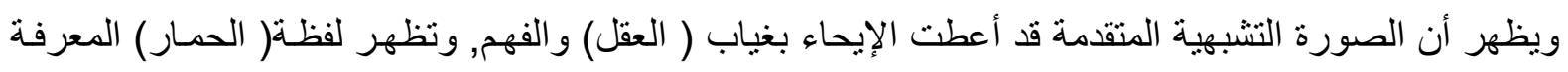

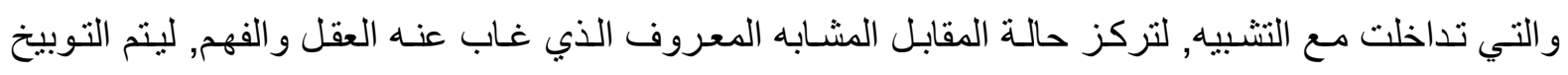

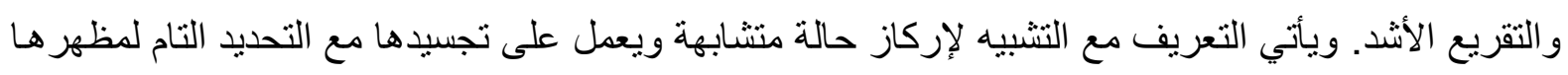

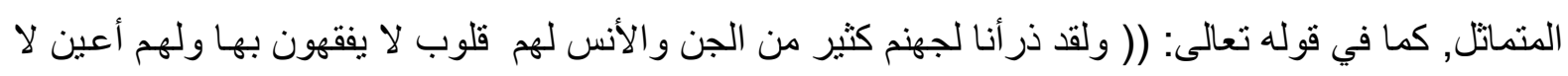

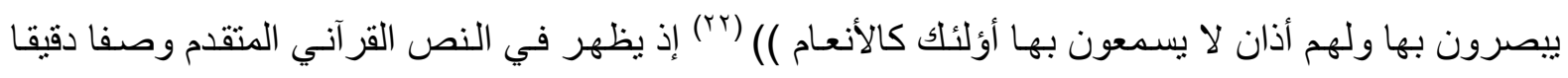

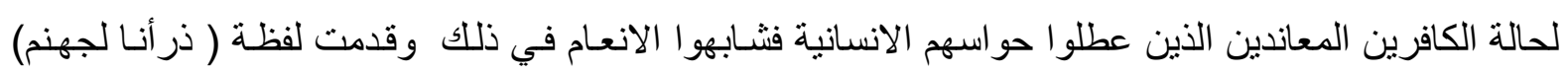




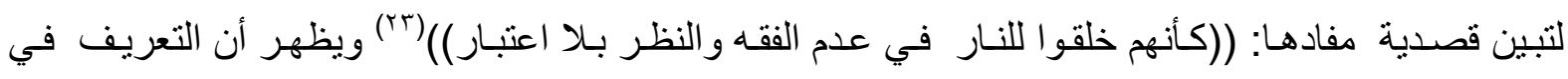
العبارة المقابلة للضالين المعاندين و هي: (الأنعام) قد أتت معرفة لتبين المقابل المرئي المعروف لهم (الأنعام) التي تكون معطلة الحواس ولا تعرف مـا ينفعها أو يضر ها, ليطفو على النص دلالة عدم الاهتداء, ويزيد النص جسامة عبارة (بل هم أظل سبيلا) لتعطي الضلالة الخاصة بهم والتي تتجـاوز ضـلالة الأنعام المعروفة. ومثال التحقير الذي عمل على صنعه أسلوب التعريف مع التتبيه التمثيلي, مـا جاء في قوله تعالى في وصف

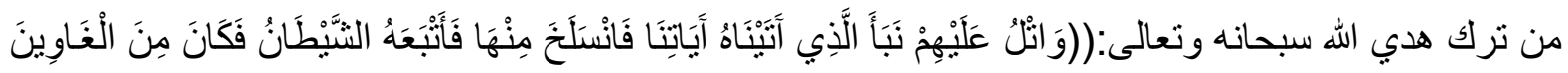

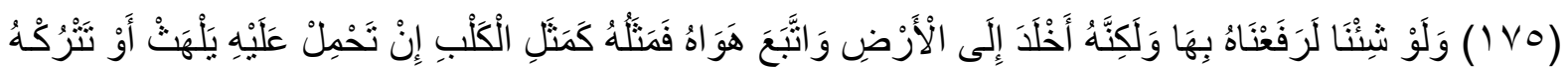

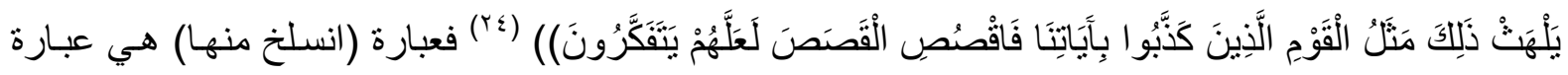

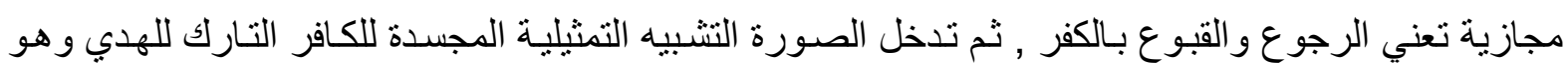
ير اه أمامه بدلائله بعبارة ( مثلك كمثل الكلب....يلهن) ويبدو أن الأفعال( يلهث, تحمل عليه, تتركه) جاء لتجسيد الفعل النفسي الذي يتوطن نفس الكافر الموغل بالإلحاد, وفي ذلك تحقير لله, وتأتي لفظة (الكلب) معرفة في لهي (مثله كمثل الكلب) لتزيد من دقة الصورة وعمق التحقير فالموصوف هو كالكلب المشـاهد المرئي حقيقية أقرب للتصديق و أقرب للفهم. وقد تعكس الحالـة المتقدمـة فيأتي التعريف مـع المجاز التشبيهي ليثير دلالـة التفخيم

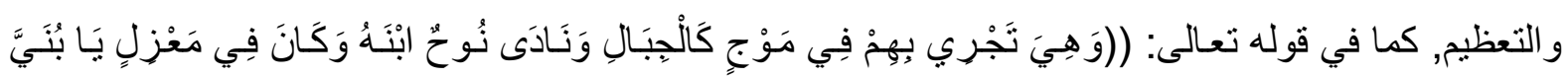

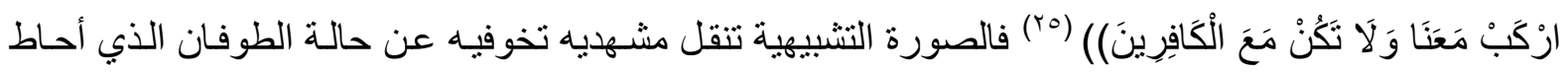
بسفينة نوح (عليه السـلام) , ويتم التقابل بين( موج) الذي يحمل التنكير و( كالجبـال) الذي يحمل التعريف , ويظهر أن التعريف المتقدم عن طريق وصف الموج بصورة الجبال المألوفة العالية قد أتنارت طسابع الخوف من

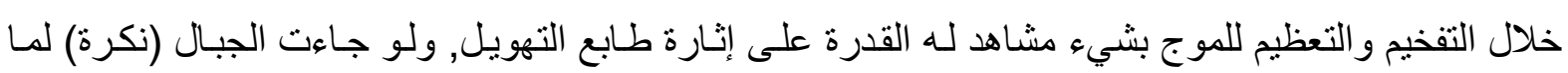
نقلت الدلالة المتقدمة لغياب الصورة الممكن تخيلها عن الحقيقة المبثوثة للمتلقي. وقد يأتي التشبيه مجسدا للحالة المعنوية, فيكون المقابل التشبيهي معرفا, لينقل دقـة المشابهة بين الطرفين عن طريق المدرك الحسي , كما في وصف الله سبحانه وتعالى لقساوة القلوب التي تبتعد عن الإيمـان بالله, كما

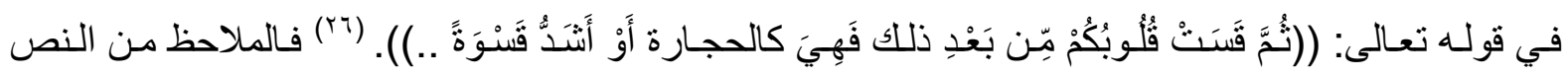
الثريف أنه قد شبه المعنوي بالحسي للإظهار والإبانة بحال الصادين عن دين الله سبحانه وتعالى ((فثبَّهَ قلوبهر بالحجـارة، بجامع القسـاوة في كُلِّ منهمـا، لكِنّ قسـاوة قلوبهم قسـاوة معنويـة تجـاه الحقّ و الخير و الفضـيلة، أمّا الحجارة فقساوتها ماديّة.)(بV) وبهذا فتطويق المعنوي( حال النفس غير المهنديـة) بإطسار مـادي مماثل مشـاهد (الحجارة) قد بين عمق القسوة الكامن فيها, و لا يخفى أن المقابل التتبيهي( الحجـارة) قد جاء معرفا ليبين أن بـأن المماثل للقساة المتقدمين, هو الحجارة المعروفة القاسية, عديمة النفع لتتأطر الصورة بإطار حسي مرئي. ب ـ أثر التتكير على المجاز التشبيهي: ويأتي التنكير متو اشجا مع المجاز التشبيهي, ليبث للمتلقي صورة التقليل

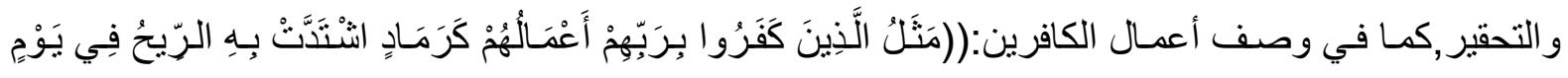

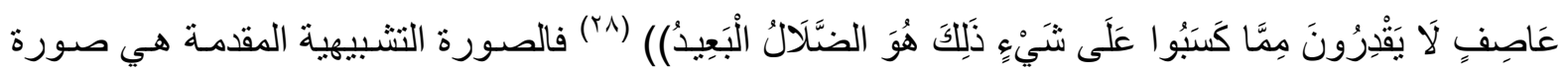


تشبيهية تمثيلية, متحركة( فأعمال الكفار) تقابل (الرماد)ــ الثيء التافه عديم النفه لتتم المطابقة بينهما, ثم تزيد الصورة جسامة من خـلال اشتداد الريح بالرمـاد المقابل لأعمال الكافرين الوضيعة, ثم إن التنكير في العبارة المقابلة للأعمال الحقيرة للكفار جاءت نكرة (كرمـاد) ومعنى ذلك: إن هذا الرمـاد هو رمـاد غير معروف وقد

غابت قيمته, و إن كانت غائبة أصلا, ليزيد النص بهذا الأثر إيحاء بتحقير أعمال الكافرين و غياب النفعية فيها. وربمـا عكس التتكير الحالـة السـابقة مـن التقليل ليخلق صسورة من الاتسـاع والتعظيم ,الأمر الذي لا يستطيع المجاز وحده أن بحققه, كما في وصف اتساع الجنة في قولـه تعالى: ((وسـار عو ا إلى مغفرة من ربكم

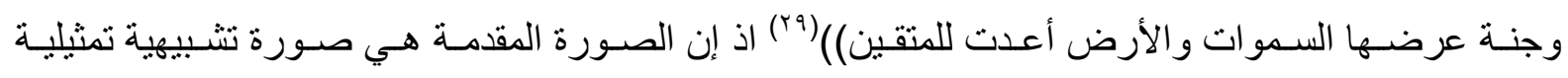
صورت اتساع الجنة عن طريق العرض ويبدو أن هنـاك قصد في تعبير الاتسـاع إذ ((استعمل العام مـع العام فلما جاء بالسموات فال: (عرضها السماوات والأرض ) ولما جاء بالسماء التي هي أهم من السموات قال

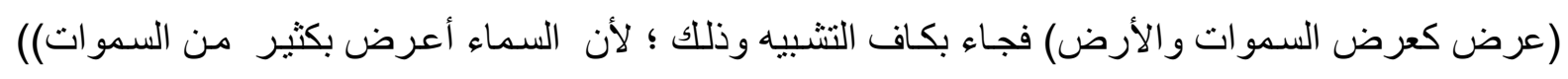

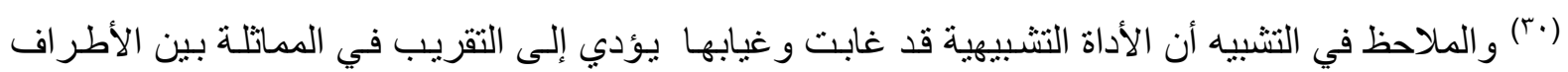
المتشابهة (اr) ولذا فالأمر واقع في بـاب الاتسـاع , ويبدو أن التنكير في لفظة (جنـة) بعبارة قد أعطى مدلول

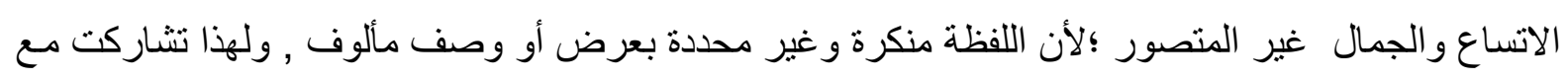
التنكير مع التشبيه في إظهار خاصية الاتساع و الجمال والتفرد. ويأتي التتكير ليؤثر في دلالة التشبيه من ناحية الكثرة و التهويل, كما في قوله تعالى: ((خُشََّعاً أَبْصَـارُ هُمْ

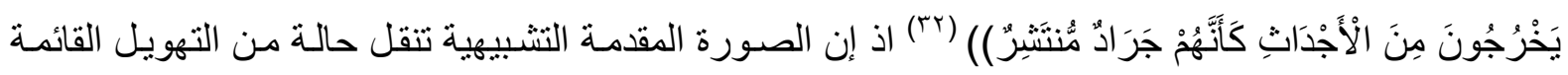
على الخروج المصحوبة بالكثرة والاضطر اب ويرى أبن عاثور أن: ((هذا التشبيه تمثيلي لأنه تشبيه هيئة

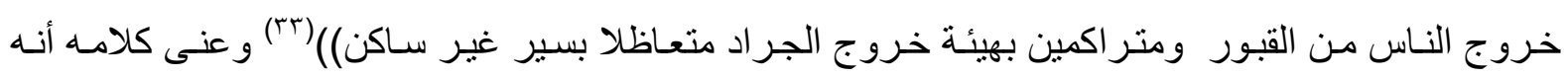
خروج مضطرب وقد أتى التنكير في ( كأنهم جراد) لتنقل لفظة ( جراد ) تنكير ادالا على حالة غير محدودة, وربما دعت إلى الكثرة والتر اكم , وهي قد زادت من حدة الاضطر اب ليسير النص كله من خلال اتحاد دلالية التتكير و التشبيه في حالـة التهويل في ذلك اليوم أعاذنـا الله من أهواله. ويسـاعد التتكير في إظهار دلالة عدم

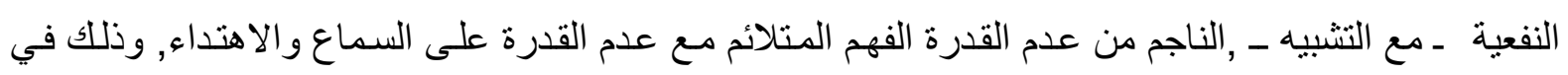

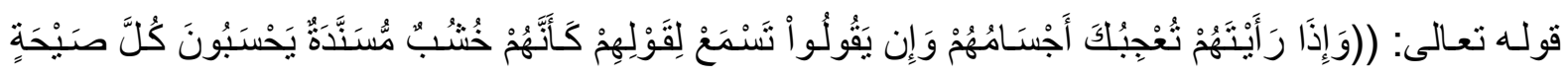

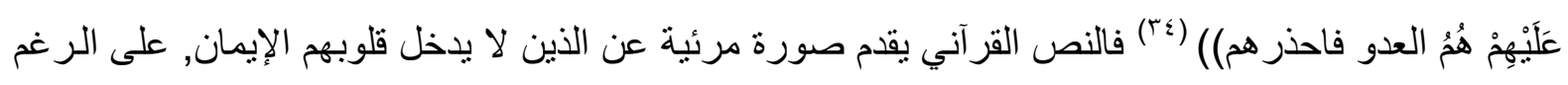
من مشاهدة الدلائل و البر اهين((ففي هذا النّص نقل صفة الجامد الذي لا حياة لله عن طريق التشبيه الصريح، و إضفاؤها على المنافقين الأحياء الجالسين المستندين إلى جدار مجلس الرسول بأجسـامهم الََْهِيَيَة، لأنّ حالتهم

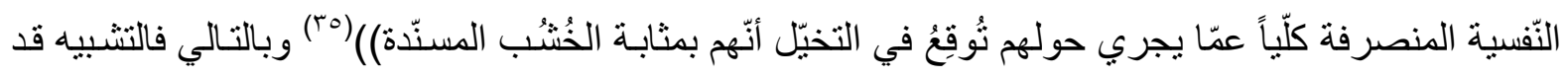
أضفى انتفاء النفعية من الدلائل, مع هؤلاء, فهم كالخشب, وتدخل لفظة( مسندة) لتزيد التشبيه دلالة بعدم النفع, فهم مسندون لا حاجة لهم, ويدخل التنكير في مفاصل التشبيه (خشب مسنده) ليزيد النص دلالة في عدم النفعية, فهذه (الخشب) المقابلة للمعاندين, هي غير ذات قيمـة؛ لأنها غير محددة المعالم و لا الاستعمال, لذا فهي أثببه 
بالثيء المتروك عديم النفع و الله العالم. ومثال اجتماع التنكير مع المجاز التشبهي والذي يعطي انتفاء النفعية ,

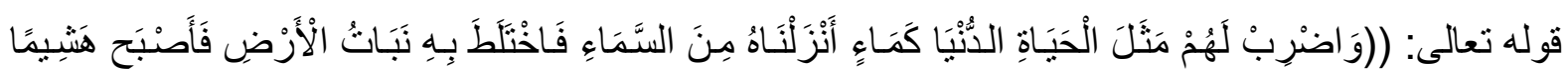

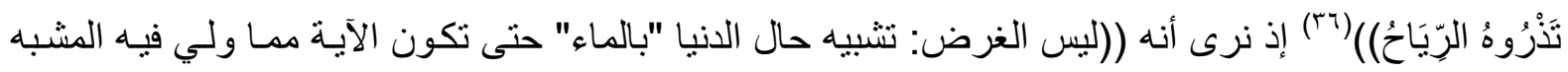
به كاف التشبيه. بل المراد. نتبيه حال الدنيا في نضارتها وغضارتها، وما يعقب ذلك من زو ال متاعها، وامحاء

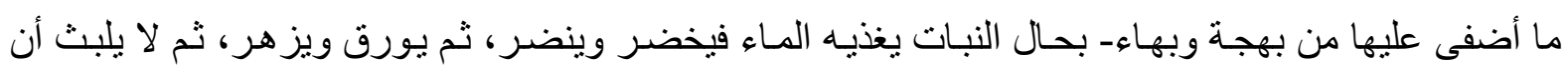

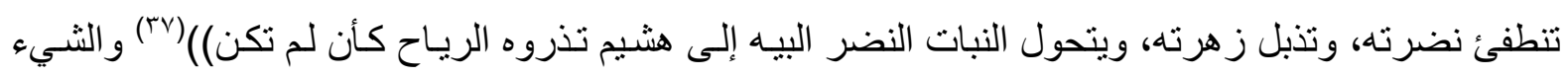
المتقدم قد أضفاه التشبيه بدلالة عدم النفعية, وز اد عليه مجيء التتكير فيه (مـاء) الذي زاد من حدة عدم النفعية فهو ماء غير محدد إضافة لاختلاطه بـالأرض وضياعه لتقف الصورة المشكلة من التنكير والمجاز التشبيهي وليه

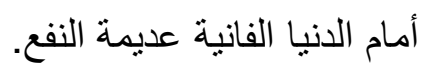

*وقد يأتي اتحاد دلالة التتكير مع التشبيه مغاير اللحالة السابقة, فيعظم من النفعيـة ويجسد أثز هـا, بصورة حسية,

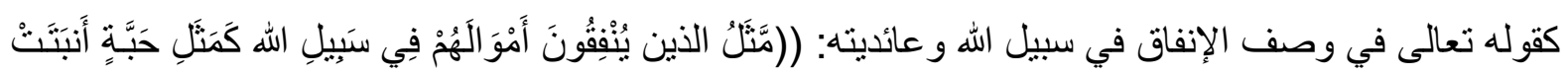

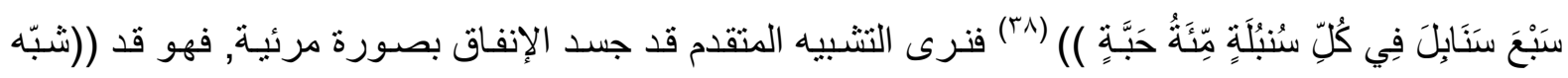

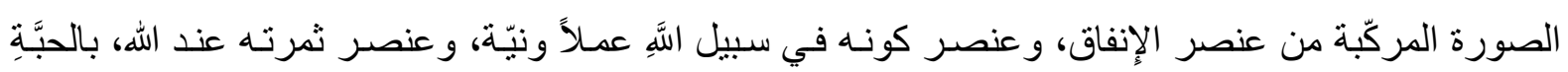

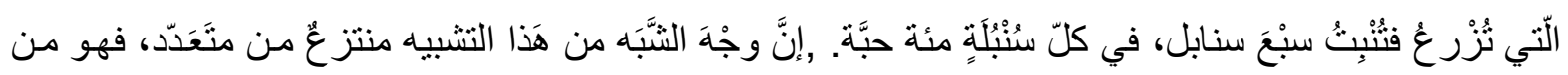

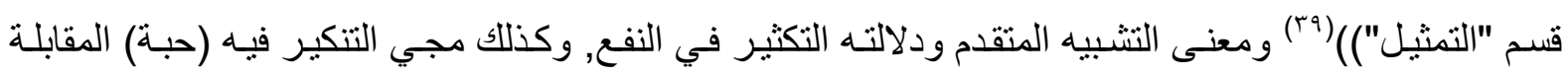
للإنفاق قد جاء غير معرف, فهذه الحبة تقع عليها احتمالات متنوعة وحتمـا تكون كلها الاحتمـالات الحسنة هي الأولى, فالحب أنواع منه الرخيص, ومنه الباهض الثمن, ومنه النادر, و هي أعلاها درجة. و الله العالم.

\section{ثانياه أثز التعريف والتنكير على دلاالة المجاز والاستعارة:}

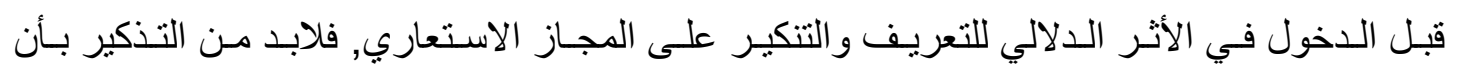

الاستعارة: باب كبير في مجاز القرآن, وفي كلام العرب, وهو من أقوى صيغ المجاز لعظم المبالغة فيه ؛ لتمام التقريب بين المستعار منه, و المستعار له ــ والاستعارة: هي: أحد أبواب البيان من علوم البلاغة العربيـة التناث,

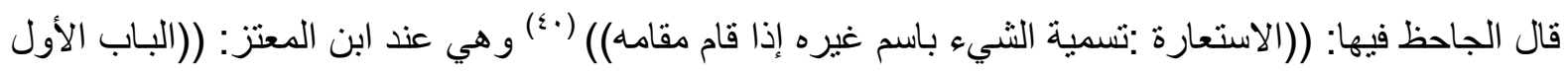

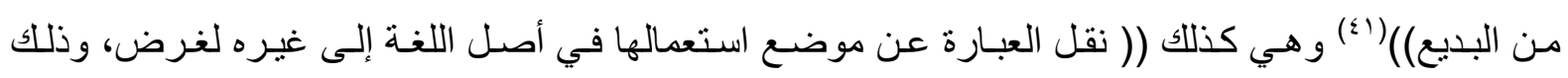
الغرض إما أن يكون شرح المعنى وفضل الإبانة عنه، أو تأكيده و المبالغة فيه، أو الإشارة إليه بالقليل من اللفظ، أو تحسين المعرض الذى يبرز فيسه؛ وهذه الأوصـاف موجودة في الاستعارة المصيبة؛ ولـولا أن الاستعارة

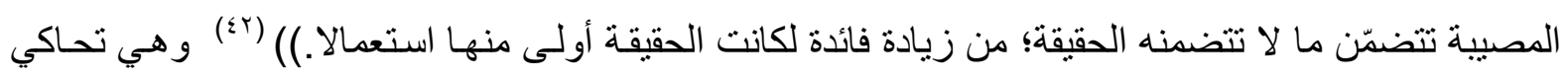
التشبيه في معناها يقول عبد القاهر فيها: ((هي ضربٌّ من التشبيه، ونَمَطٌُ من التمثيل، و التشبيه قياس، و القياس

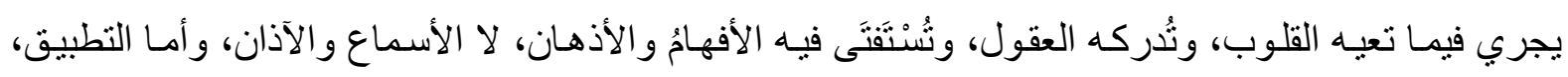

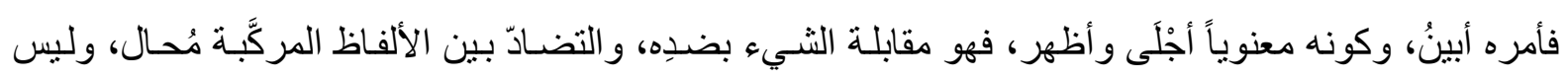

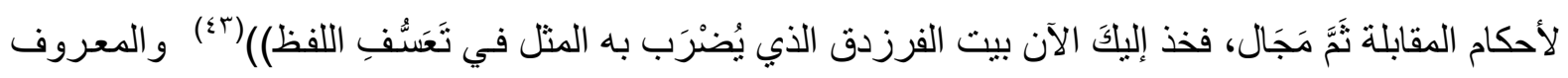


أن ((العلاقة في الاستعارة المشابهة بين المعنى المجازي والمعنى الحقيقي لأجل صحة نقل اللفظ من المعنى

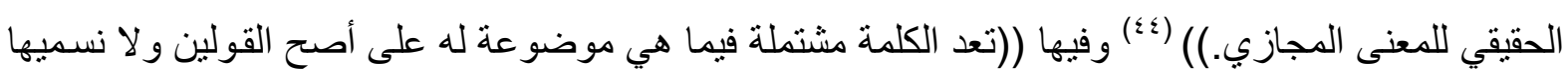

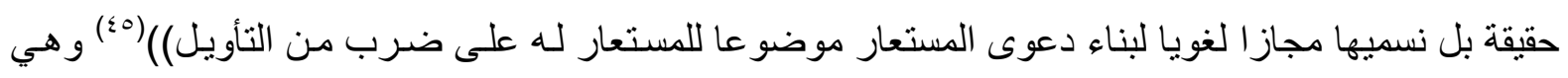

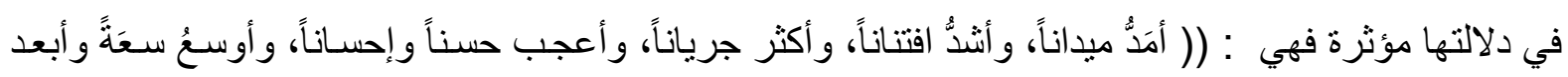

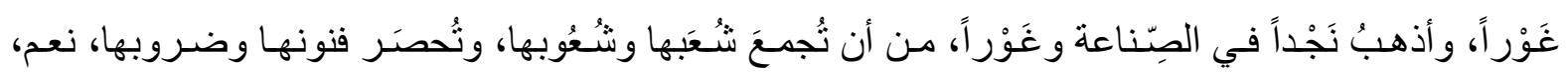

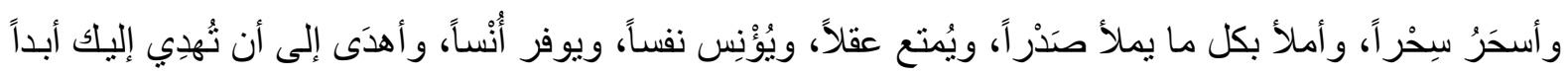

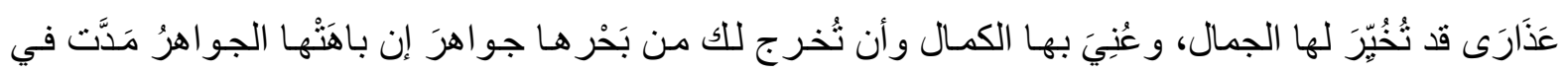

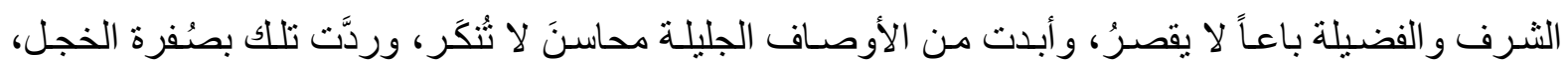

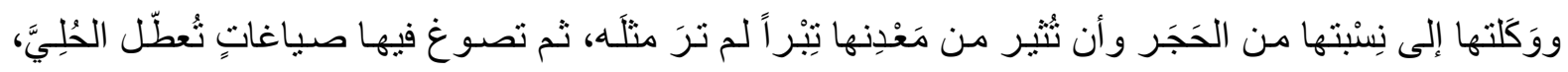

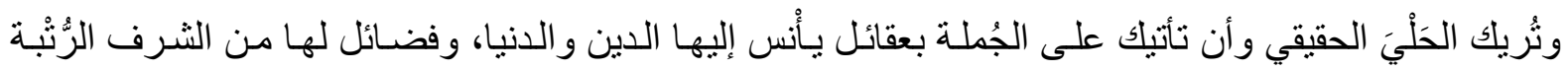

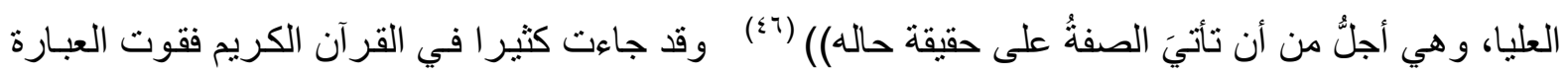

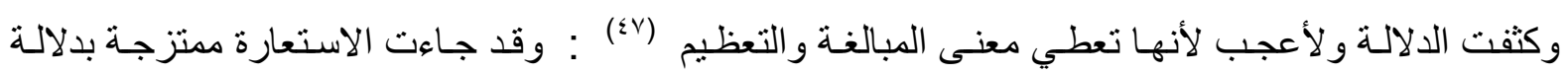
التعريف والتنكير, ولقد كان للأسلوب المتقدم دور كبير في إظهار الدلالة المجازية, مبالغة, أو قوة, أو غيرهـا من الدلالات المر اد بثها إلى المتلقي, كما سيأتي. أـ التعريف و أثره على دلالة المجاز الاستعاري: و التعريف هو باب من أبو اب علم المعاني ـ كمـا تقدم ذكره ـ وهو أنواع ومنه التعريف بالإضافة, وقد يأتي التعريف بالإضـافة, فيؤثر في دلالة المجاز الاستعاري, فيعطيه

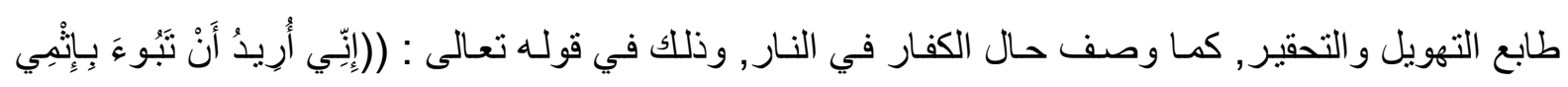

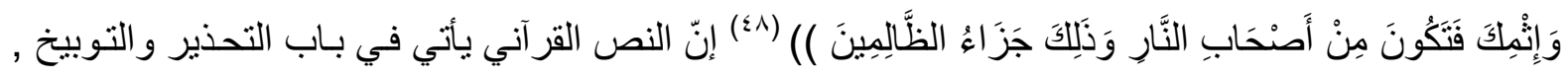
فالأخ يريد أن يقتل أخاه ظلما من غير وجه حق فيأتي المجاز ليبين صورة العذاب التي يمكن أن تلحق بـه فيمـا

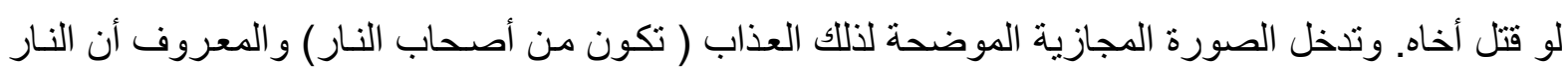
في ملكيتها لا تعود سوى لله ـ سبحانه وتعـالى ـ ولكن هذا الإسناد هو إسناد مجازي من بـاب الإقامة الدائمـة و التهويل في العذاب, ويدخل التعريف بالإضـافة في مفاصل المجاز من خـلال عبارة( أصحاب النـار) لتبين الدلالة المخوفة فيصبح الأخ المالك المعروف غير الخفي فالنار ملك له وهو معروف بها فيها_ـلـو قام بفعله الثنيع - , وبهذا فالتعريف قد عمل على زيادة الدلالة الر افدة للتخويف و التهويل و التي استبطنها التقريع الثديد. ويأتي الاسم معرفا ( بأل) فيرفد الصورة المجازية الاستعارية قوة فتصف حالة العذاب الأخروي وتزيد من

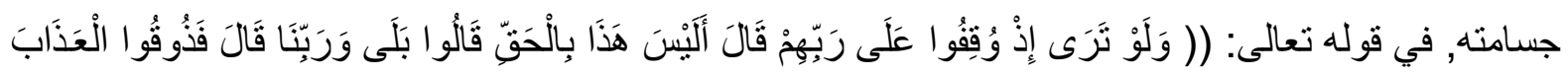

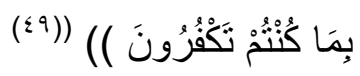
الصورة الاستعارية المقدمة تصف صورة العذاب الأخروي وحال الكافرين في النار رقال ابن كثير : (وأمسا الكفار فتوزن أعمـالهم، وإن لم تكن لهم حسنات تنفعهم يقابـل بهذا كفر هم، لإظهار شقائهم وفضيحتهم على

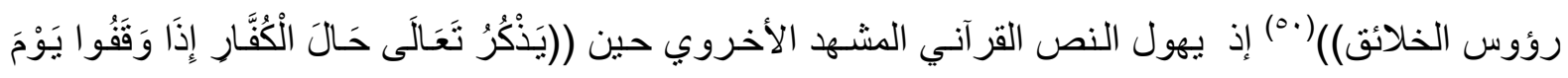




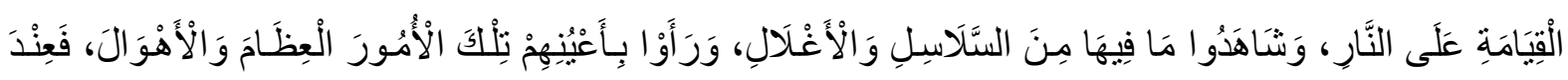

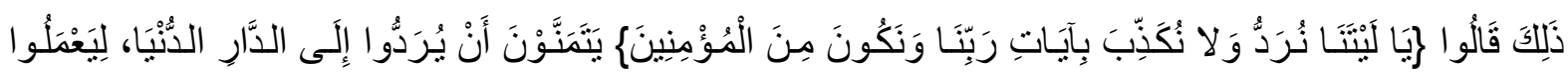

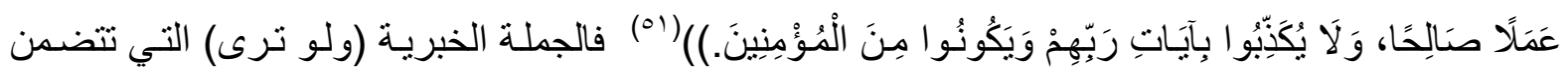

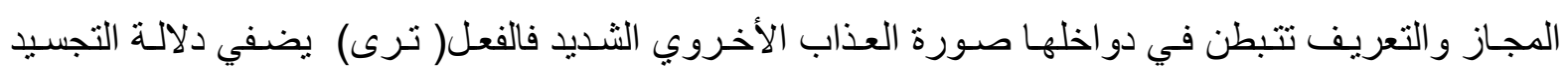

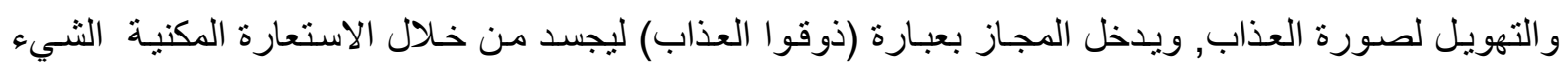

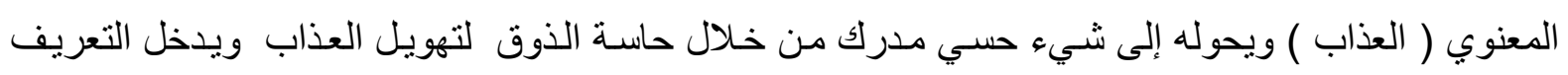

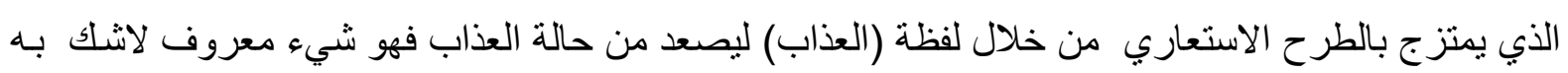

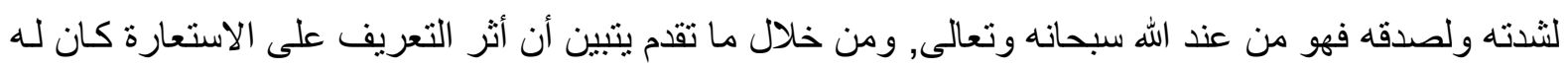

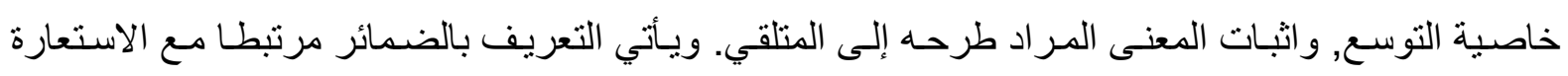

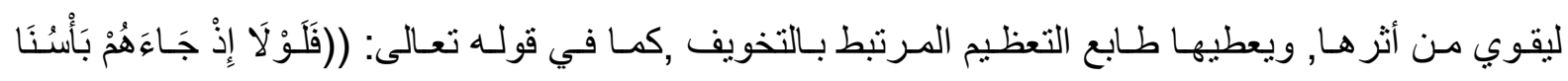

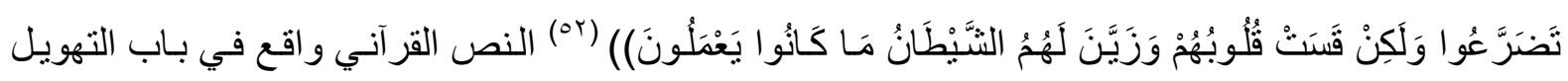

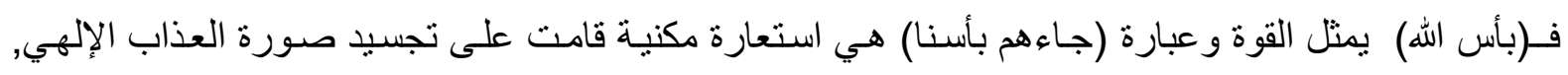

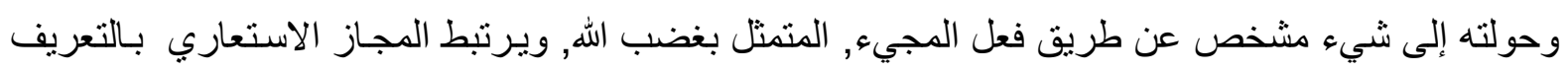

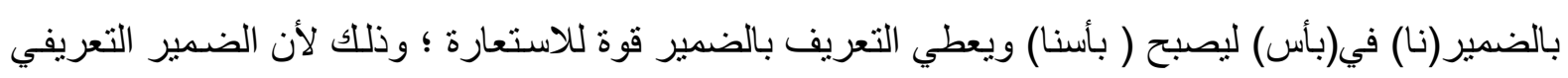

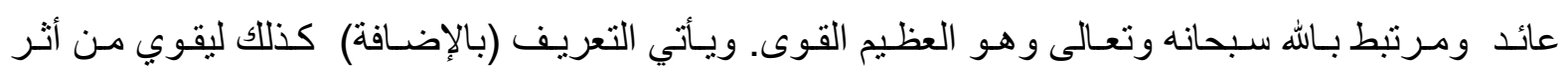

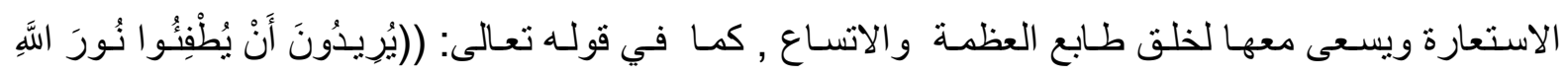

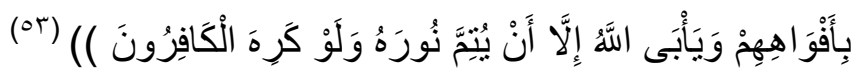

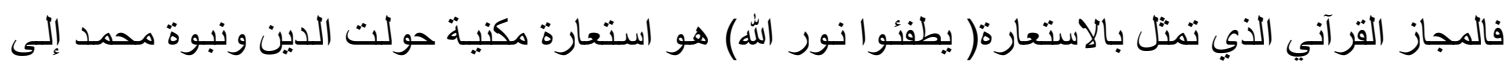

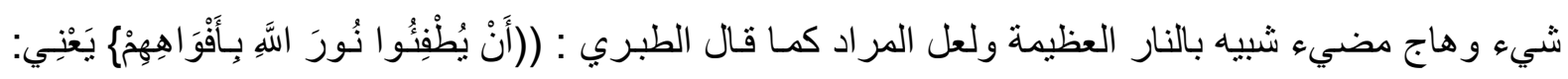

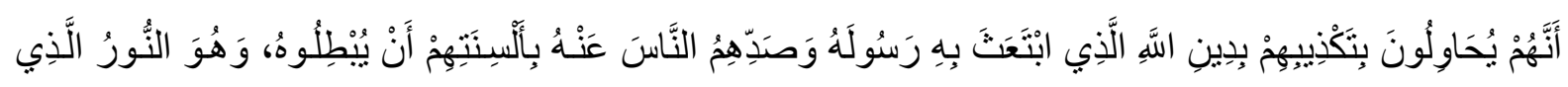

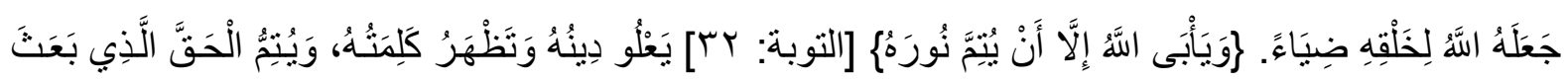

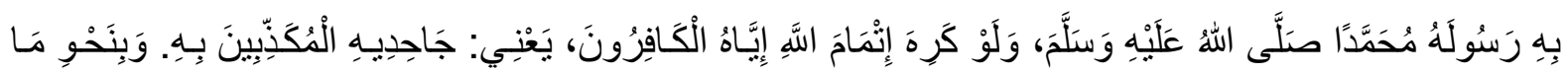

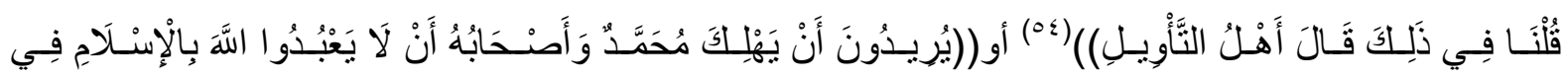

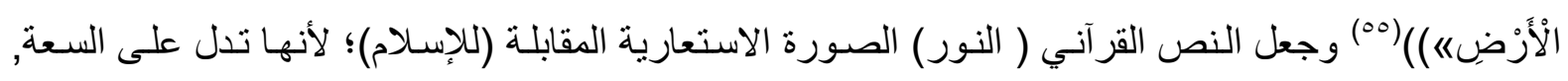

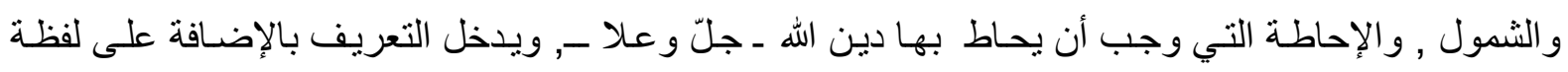

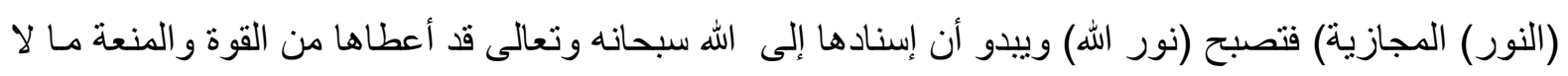

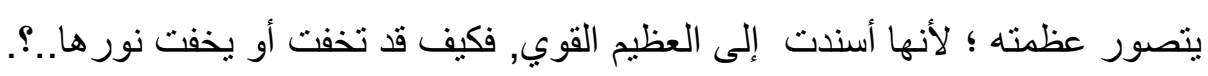
ويأتي (التعريف) متلازما مع المجاز الاستعاري ليبين حالة شُدة البأس الرباني الموجه للكافرين المعاندين,

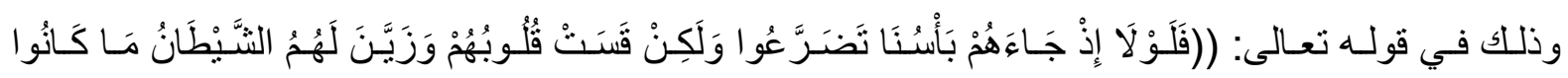

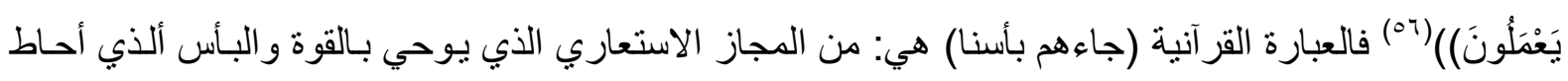




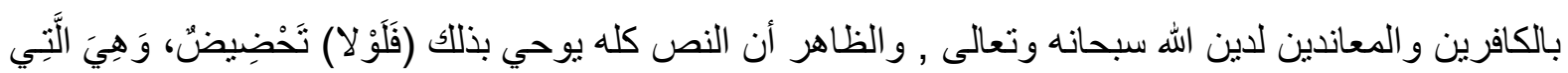

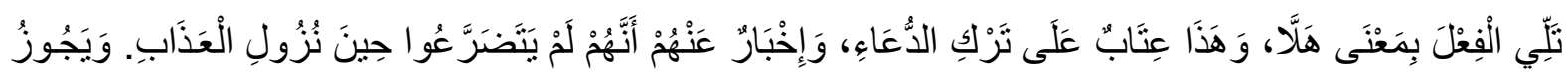

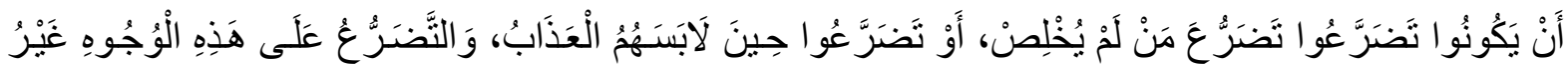

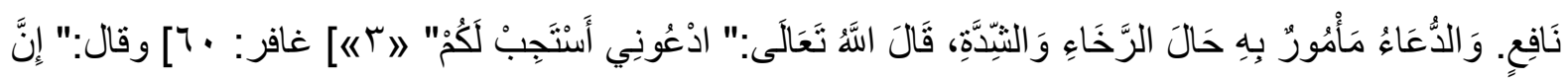

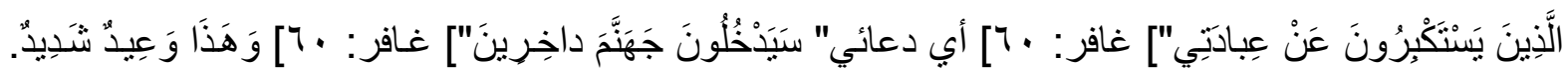

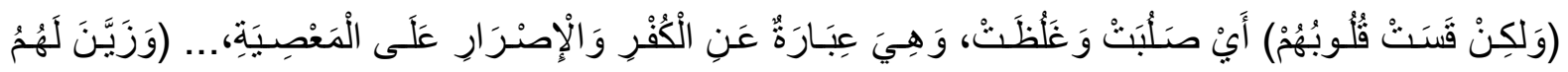

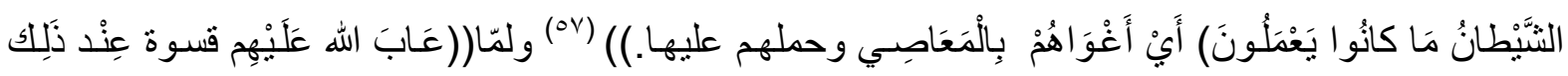

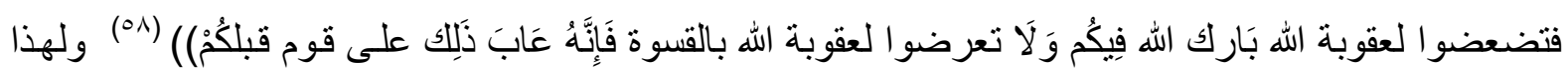

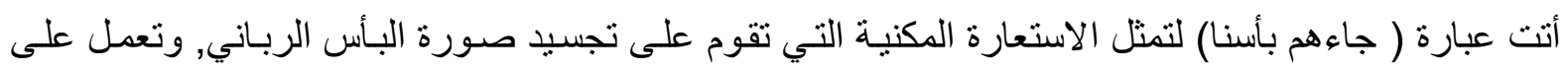

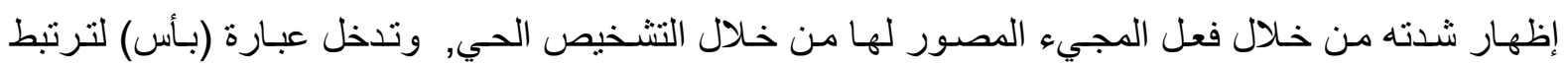

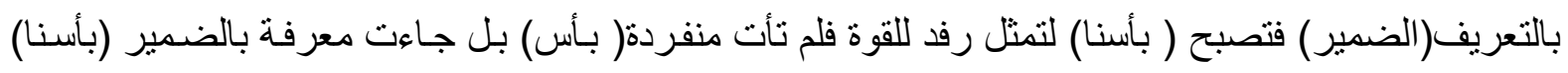

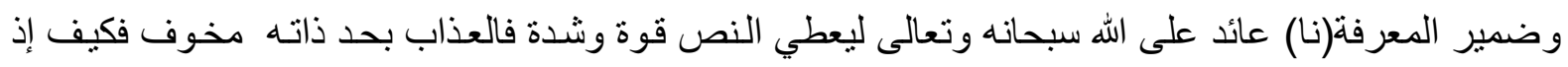
ارتبط بالله سبحانه وتعالى القوي العزيز.

وقد يتكاتف التعريف و التتكير مع المجاز القرآني الاستعاري ليجسد الصورة المقدمة إلى المتلقي ويبين

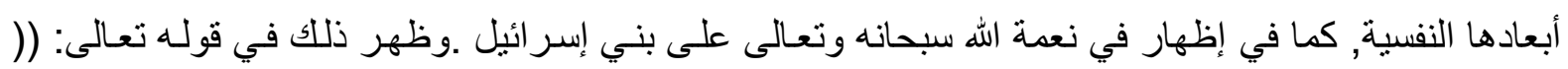

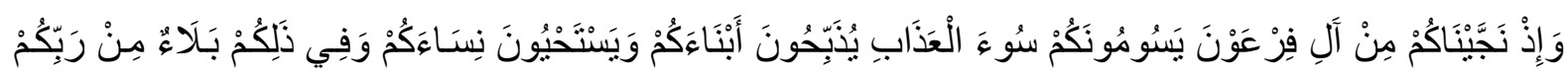

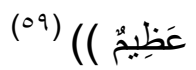

إذ تبين العبارة المجازيـة (بيسومونكم سـوء العذاب) البعد العظيم والتجسيدي لعذاب (آل فرعون) لقوم

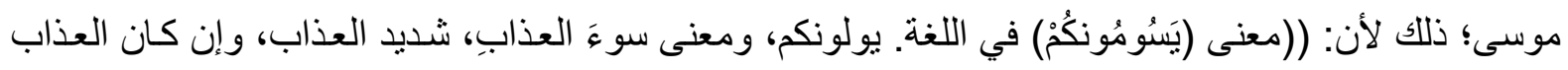

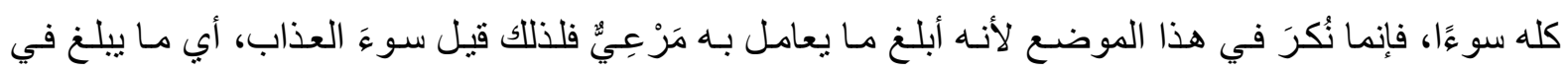

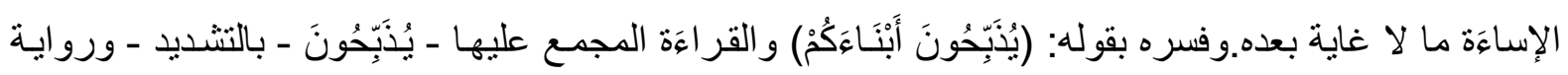

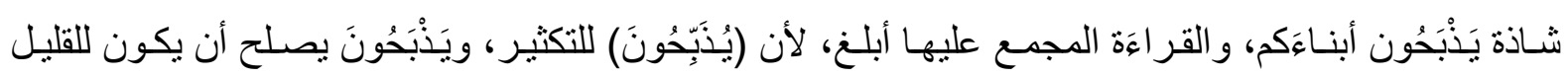

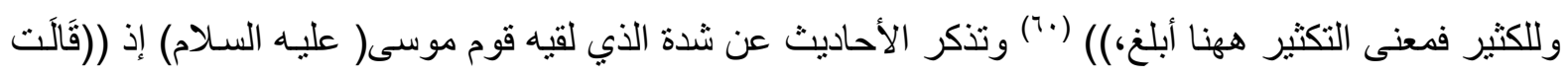

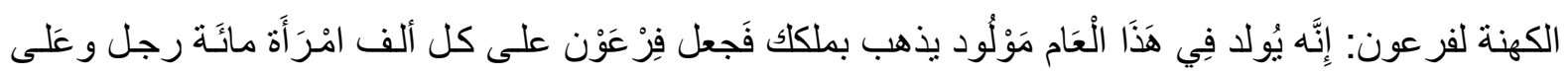

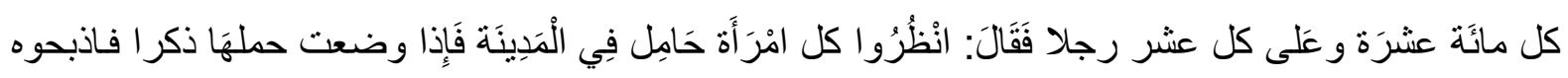

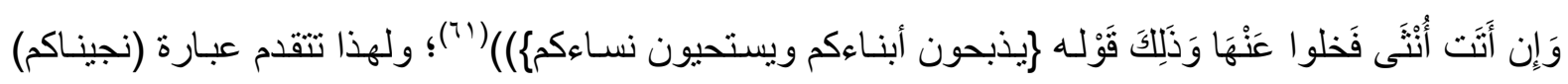

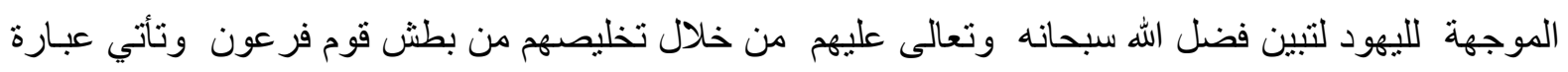

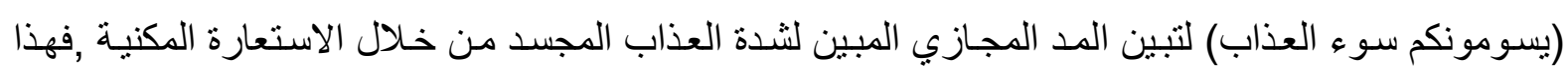

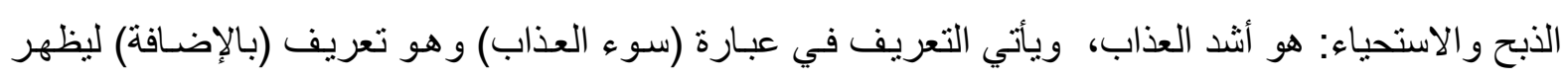

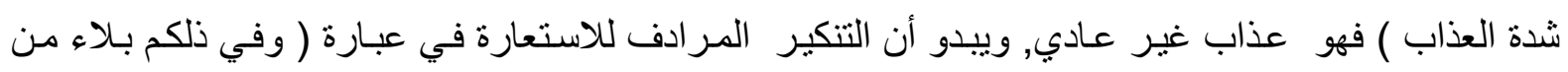


ربكم عظيم) وفي عبارة (بلاء, عظيم) هو إكمال لصورة العذاب ومن خلال ذلك تم الكثف عن شدة العذاب,

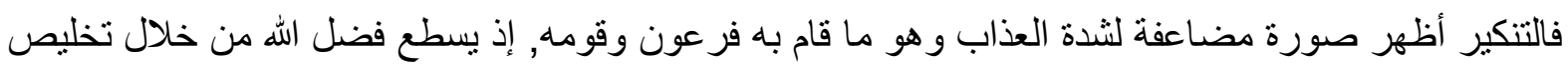
بني اسر ائيل من هذا العذاب.

ويأتي المجـاز الاستعاري ليضـع المقابلات المهمـة أمسام الدقابلات الأخرى التي يختفي أثرهـا , ويأتي

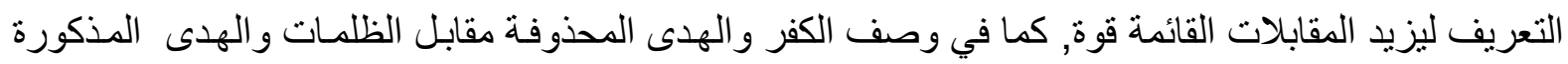

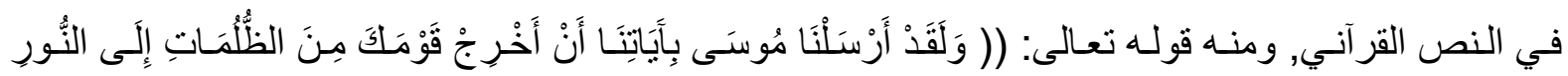

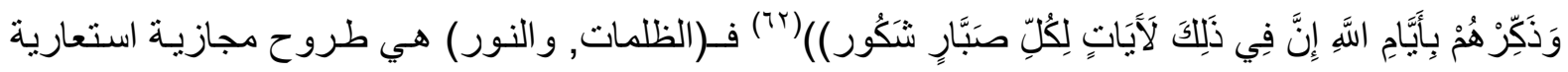

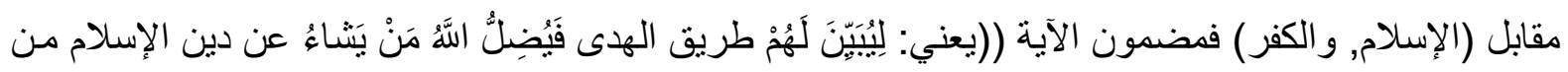

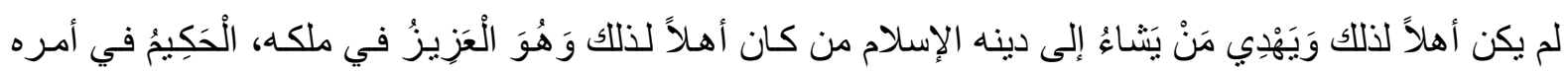

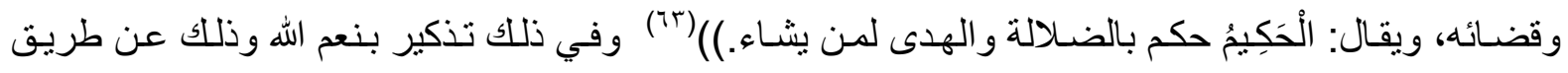

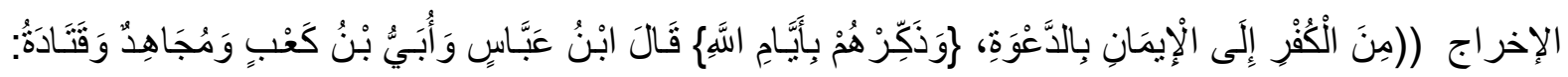

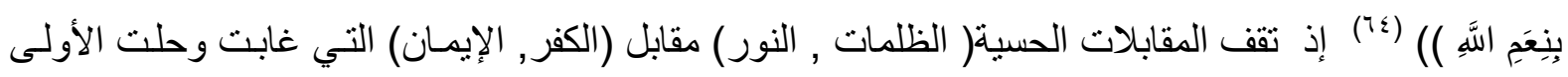

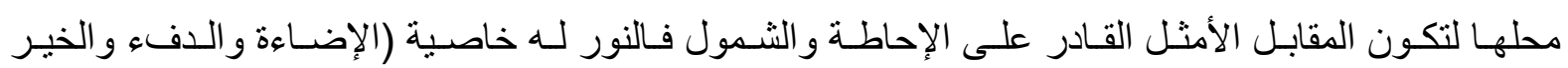

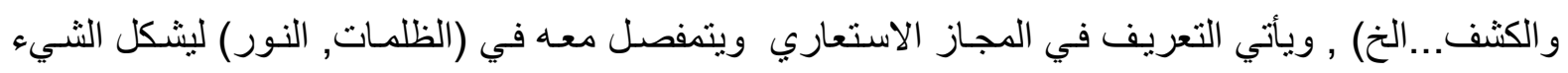

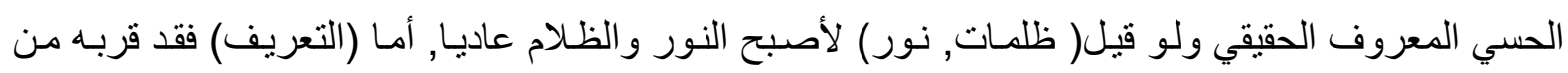

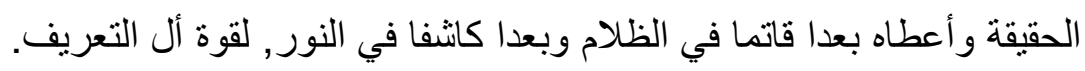

ويدخل (التعريف) على الطرح المجازي الاستعاري فيعطيه قوة, ـ خاصـة ــ إذا كانت الصورة بصرية

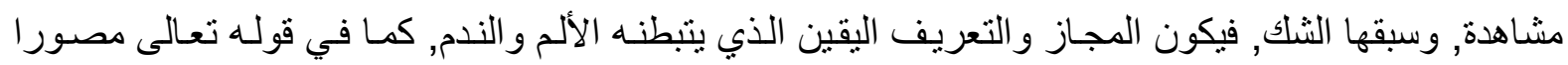

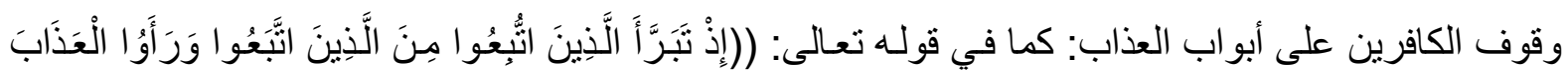

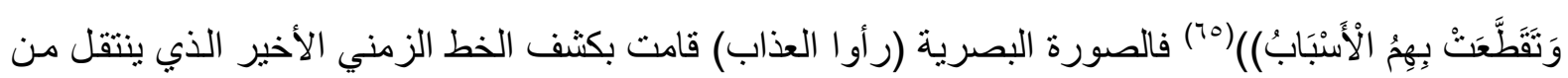

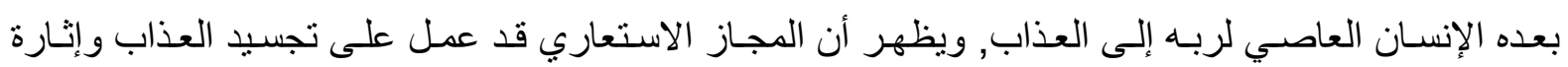

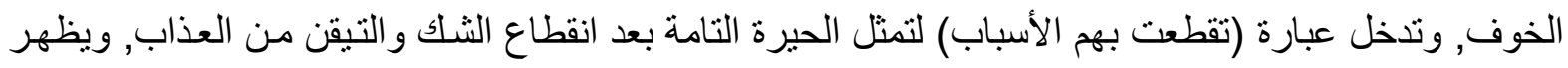

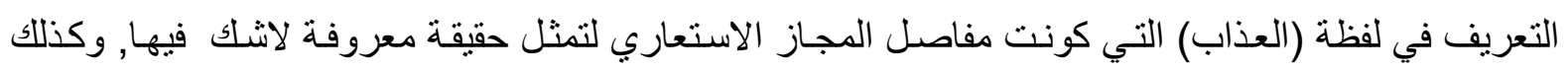

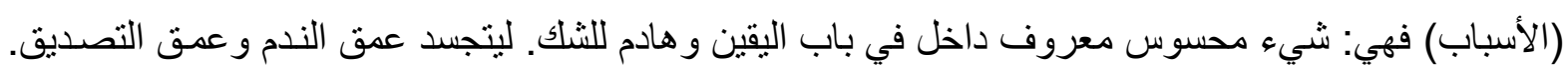

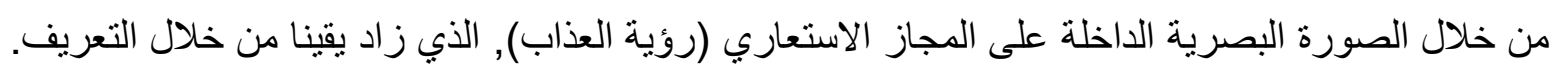
وقد يأتي (التعريف بالإضافة ) متر ادفا مع المجاز الاستعاري, وذلك للتنكير, الممزوج بالتوبيخ, كما في

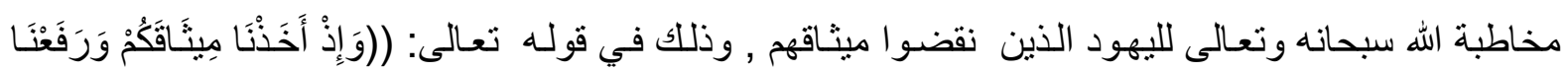

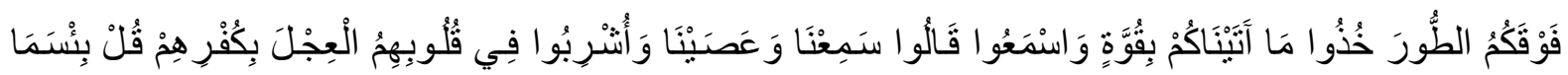

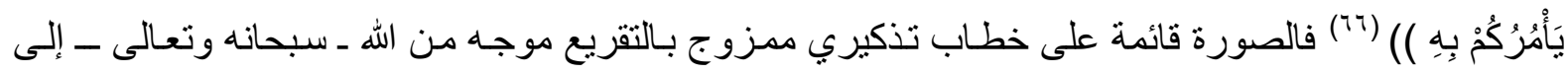

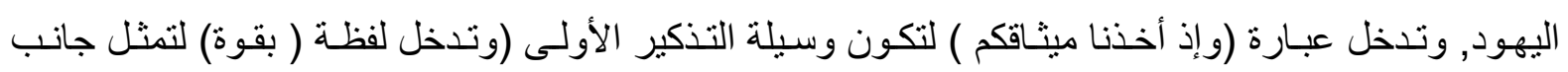


الطرح الأكمل الذي يتطلبه, العهد الرباني, ليرتبط ذلك بلفظة ( ميثاق) التي تؤلف التشكيل الاستعاري الذي جعل العهد بين العبد وربه عن طريق الاستعارة التصريحية (ميثاقا) ليعطيه القوة والثدة, (فالميثاق) أنثبت من (العهد), ثم يدخل ويرتبط التعريف بالضمير المتقدم فيصبح( عهدكم) العائد على اليهود , ليطفو على السطح عامل التذكير, فهو عهدهم هم , وهم الذين قطعوه على أنفسهم , وكذللك بمتزج بـالتقريع القائم على المسـار

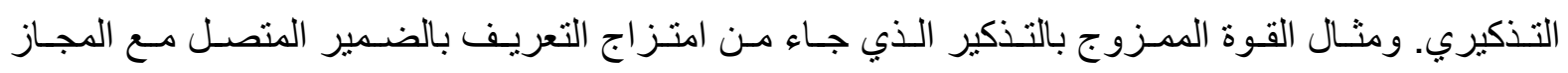

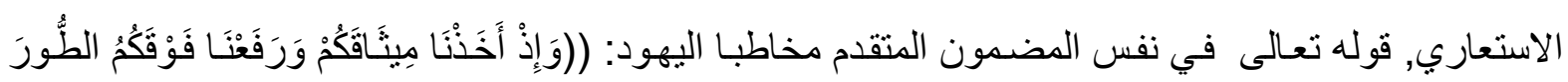

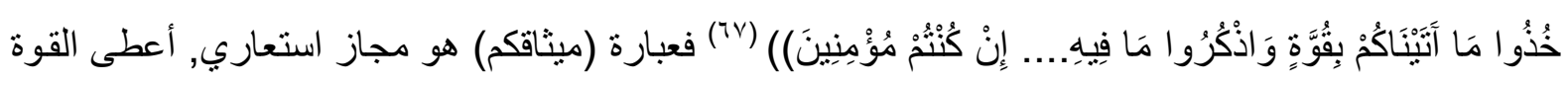
في العهد الذي استعير لـه, ويدخل (أسلوب التعريف) مـن خـلال الضـمير(كم) المتصـل بالاستعارة(ميثاقكم) ليفضي بالتذكير الممزوج بالقوة, التي يتطلبها الطرح المقدم.

بـ التنكير و أثنره في دلالـة المجـازي الاسـتعاري: وللتنكيـر دلالات متنوعـة تـؤثر في فاعليتهـا على المجـاز

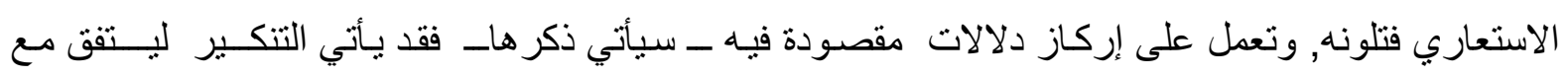

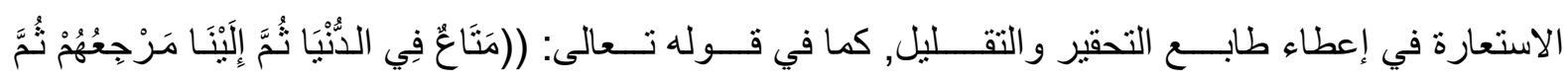

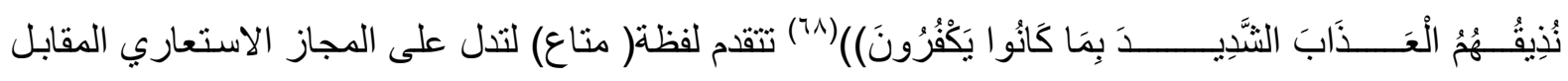
(لحصاد الدنيا ) ومكاسبها وملذاتها, ورغم حجم الضخامة التي يظنها الإنسان في هذا الكسب, ومدى الجهد الذي يناله منه إلا إن النص القرآني يحجمه ويصغره من خلال لفظة( متـاع) المتقدمة التي هي في معناهـا الحرفي : (الزاد القليل) الذي لا يسد سوى في السفر القليل, ويبدو الارتباط بين (المجاز الاستعاري) وبين (التنكير)

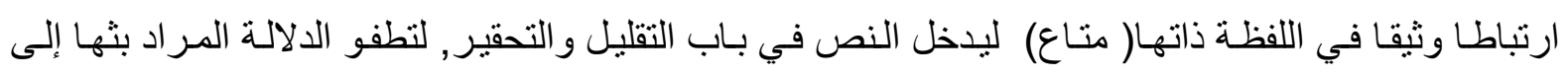
المتلقي بعدمية النفعية من الاتكال على الزاد الدنيوي قياسا بالزاد الأخروى الكبير الدائم.

وتتكاتف دلالة التنكير مع المجاز الاستعاري لتبين شدة الحاجة الداعية للدعاء و الاستتجاد بـاله سبحانه

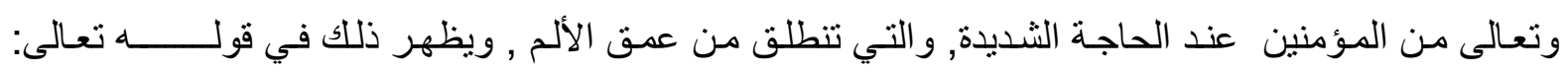

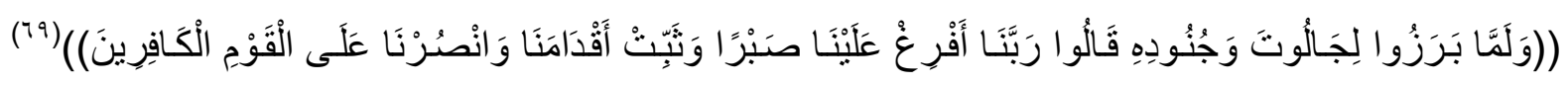
فالنص القرآني يضع صورة حية لمشهد لقاء المؤمنين على قلة عددهم بالكافرين الأكثر عددا ((إنـه لمشهـ مؤثر

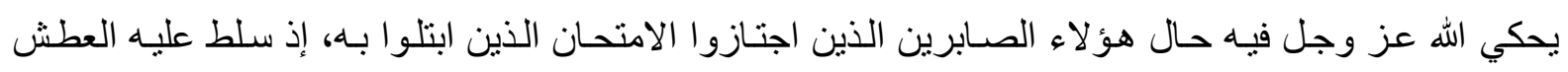
الثديد والماء بين أيديهم، فنهو ا عن الثرب من النهر إلا غرفة واحدة بيد الثـارب ثم يمسك، فلم ينجح في هذا لهات

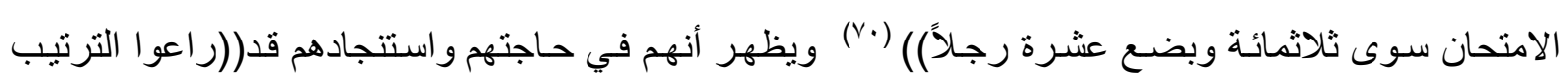

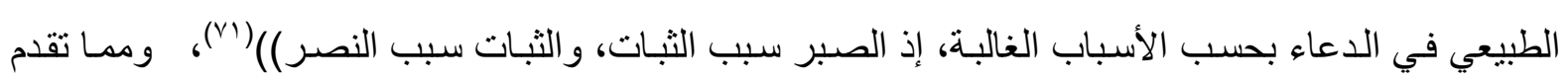
فالآية المباركة تبين المواجهة التي حدثت بين المؤمنين وبين الكافرين الأكثر عددا ولذا فالموقف يحتاج إلى

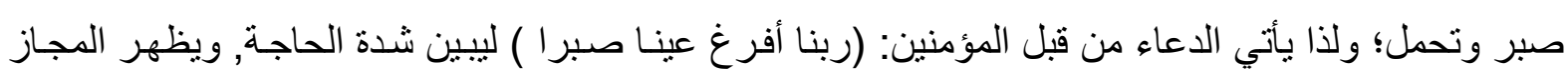

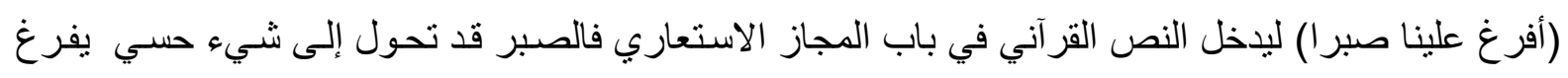
(ربنا أفرغ علينا صبر ا) ليبين شدة الحاجة له فهو مثل الماء في الحاجـة, ويظهر أن استعارة الصبر قد جاءت 
في حالة التنكير من خلال لفظة (صبر ا) التي ضاعفت من شدة الحاجة له؛ فالمؤمنون في سـاحة المعركة بحاجة إلى صبر غير عادي مع شدة العطش وكثرة الأعداء موازنة بهم. ويبدو أن عبارة (علينا) عنت الرغبـة بالثمول

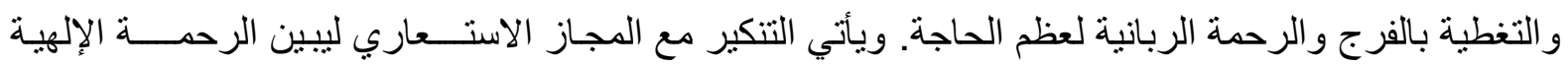

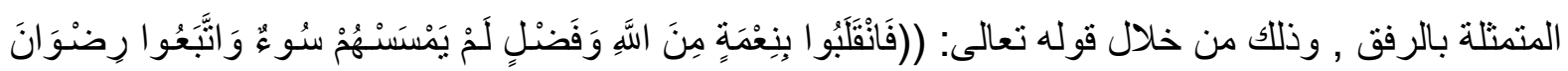

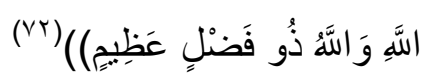

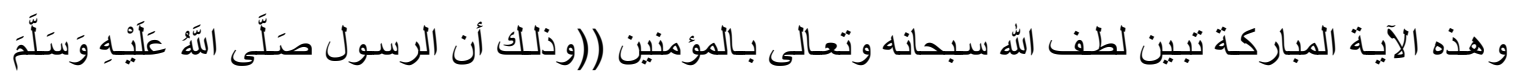

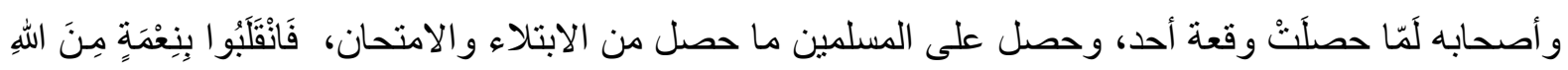

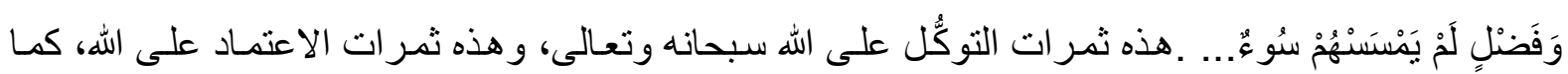

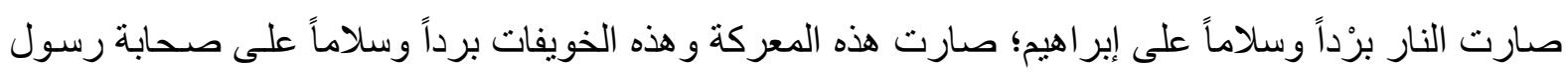

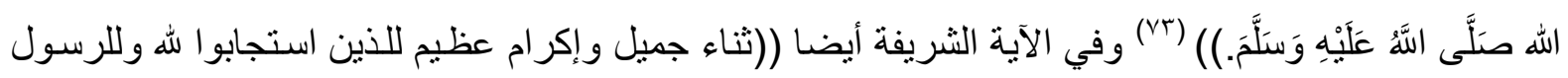
من بعد ما أصابهم القرح فقد أكرمهم الله بأن رجعوا سالمين من حمر اء الأسد فلم يلقوا عدواً بحيث كفاهم الله مـا لهاء أهمه ورد عنهم بأس الذين كفروا بقذف الخوف و الرعب في قلوبهم، ثم أثنى عليهم باتباعهم رضوان الله الذي لهن

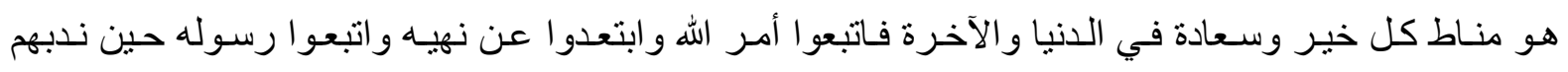
للخروج ولذلك تفضل الله عليهح بالتوفيق و السداد فيما فعلو اوظفروا بالأجر العظيم والثواب الجزيل لاتباعهم مـا يرضي الله ورسوله)(V) فحالة الرحمة والرفق بالمؤمنين تتمثل من خلال هدوء الطرح المجازي المثنل لحالة النعمة الإلهية عن طريق عبارة (لم يمسسهم سوء) و(السوء) هو: حالة معنوية , والاستعارة عملت على تجسيده بالتمثيل ,وقام النفي( لم يمسسه) بقمع أثره ويبدو أن لفظة سوء) التي تباعدت عن المؤمنين قد جاءت في حالة

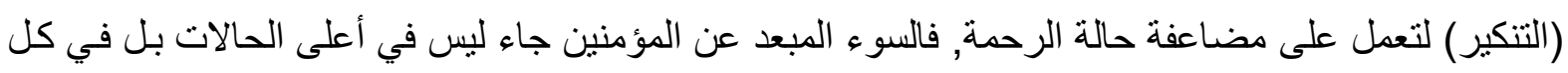
الحالات و أقلها, فالتنكير هنا جاء للتقليل والتحقير من صغر الثيء فلا السوء القليل أصابهم, و لا السوء الصغير الحقير ألم بهم وأز عجهم, وتللك من رحمة الله سبحانه وتعالى حينما يحيط بها عباده المؤمنين. ويأتي التتكير مع المجاز الاستعاري ليفيد تمام القدرة الربانية وعمق اللطف و الرحمة, التي يحبط بها عباده

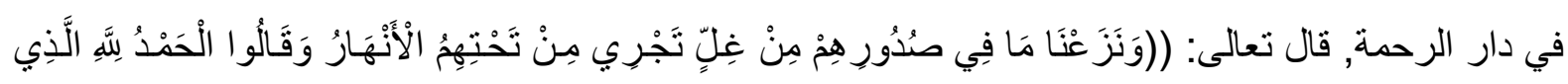

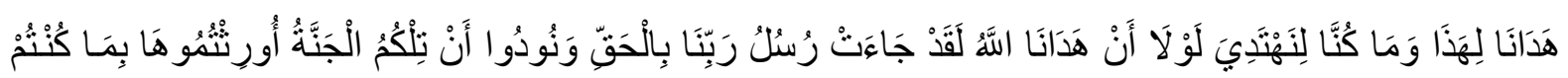

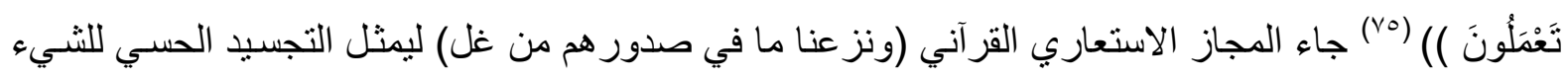

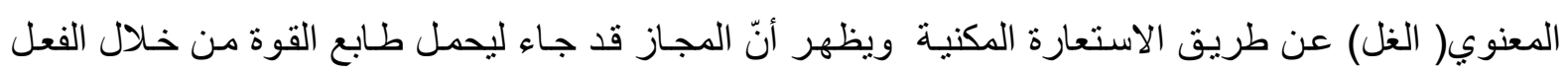
(نزع) الدال على السحب والقوة الثديدة, ويظهر التنكير المرتبط معه ( من غل) ليفيد استغر اق الجنس بدلالة (من) المتقدمة عليه, ومعنى ذلك: أي القوة التي سعت إلى ذلك و اللطف الرباني الذي جعلهم أنقياء, وتلك فعلا هي صورة الدار الآخرة: (( إنها دار الطهر و النقاء والصفاء الخالية من الأوشـاب والأكدار، إنها دار السـلام

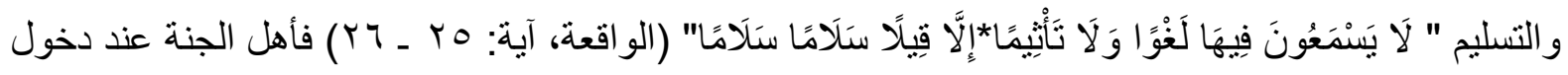

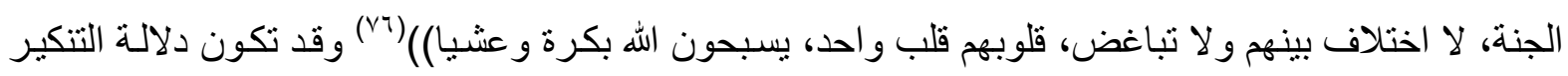




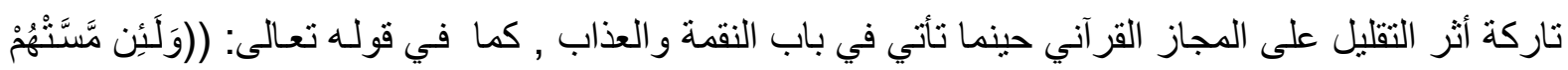

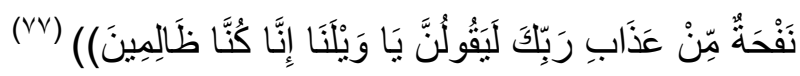
فالاستعارة هي في (نفحة من عذاب) و هي استعارة مكنية التي قامت بتجسيد الثيء المعنوي وتحويلـه إلى

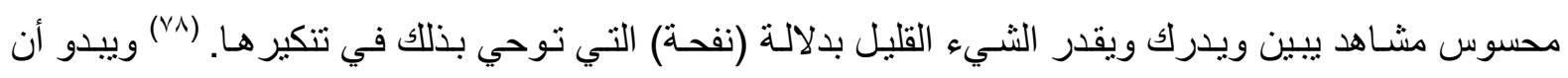

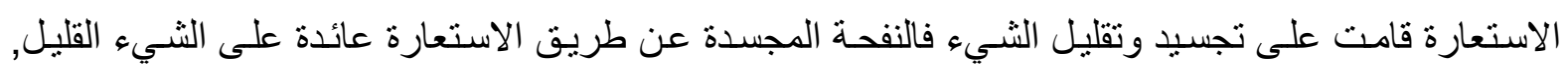
وكذلك فالتنكير المتداخل معها في لفظة( نفحة) هو شيء تتكيري قليل, لتطفو اعلى النص دلالة عدم التصبر

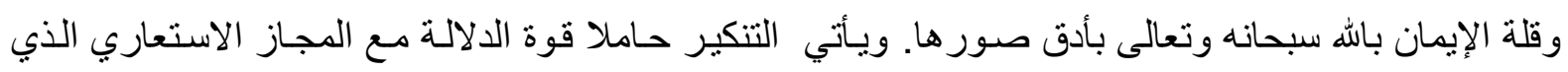

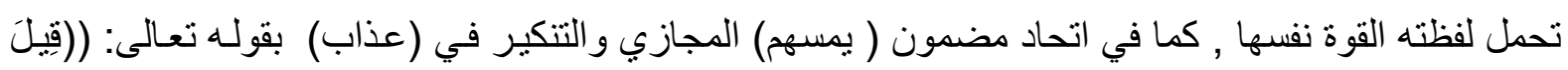

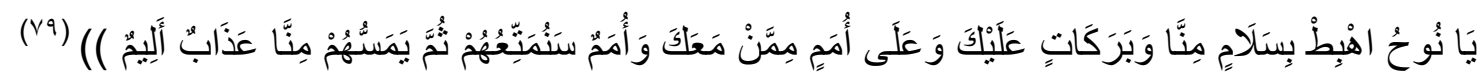
فالملاحظ أن المجاز الاستعاري قد خلق من خلال الاستعارة المكنية (يمسهم منا عذاب) حالة من التهويل إذ قام بتجسيد العذاب وجعله حسيا مرئيا, ثم إن لفظة( يمسهم) لم تحاكي الهدوء في اللمس و إنمـا حاكت القوة لأنها مشتقة هنا من (المس ) وهو: (الجنون), أي جنون من شدة العذاب , ثم إن دخول التنكير في مفصلية الاستعارة قد قوى من أثر هـا ؛ لأن لفظة ( عذاب) في التتكير جاءت لتعطي الثـدة والتهويل فيه؛ ف فذلك العذاب غير معرف , و لا معروف ؛ لأنه ليس ضدن نطاق العذاب الذي يمارسه الإنسـان على الإنسـان , و إنما هو العذاب الذي يمارسه الله مع الإنسان العاصي. ومثال تجسيد العذاب أيضا, قوله تعالى في خطاب النبي ابر اهيم لأبيه ليدخل في بـاب التحذير: (( يَا أَبَتِ

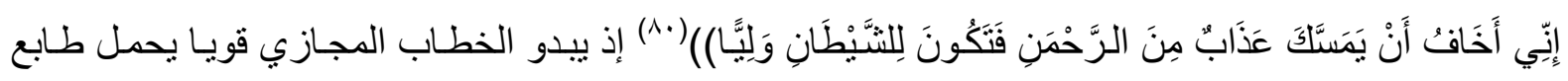
التحذير الثديد عن طريق الإيحاء المجازي الاستعاري( يمسك عذاب) وكمـا تقدم في الآيـة السـابقة فإن المجاز

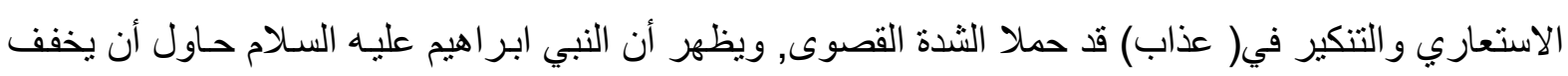

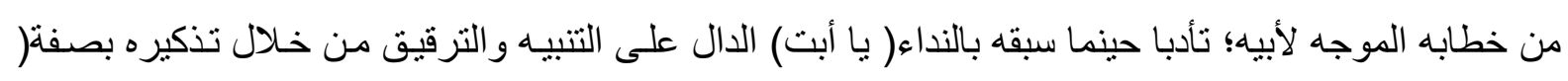
الأب) , وكذلك فعبارة (إني أخاف) قد جاء محذوفا منها لفظة( عليك) وتقدر ( إني أخاف عليك) وكأن الخوف لته

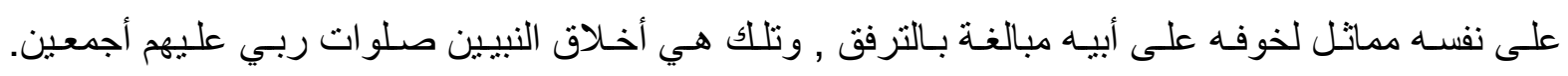
ويأني الثيء المتقدم ـ أي التنكير- مع الاستعارة ليدل ليس على الثدة بمعنى العذاب , و إنما بكمال العناية , فيمـا

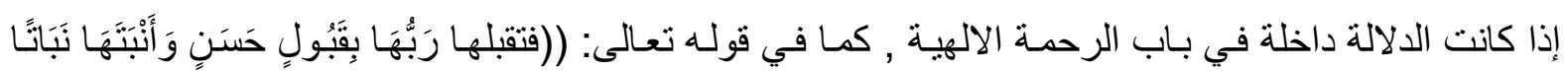

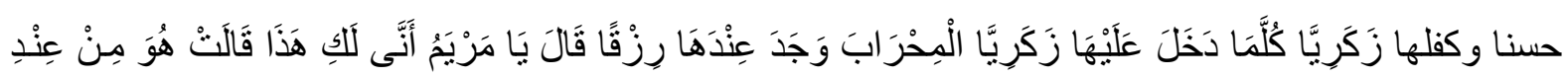

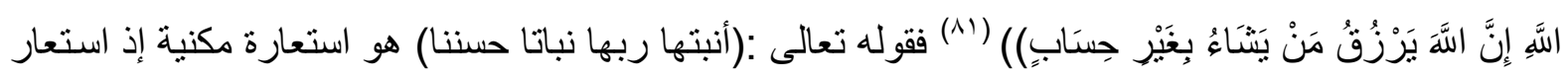

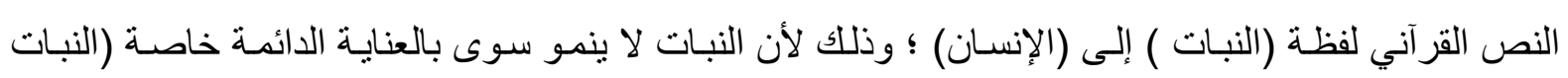

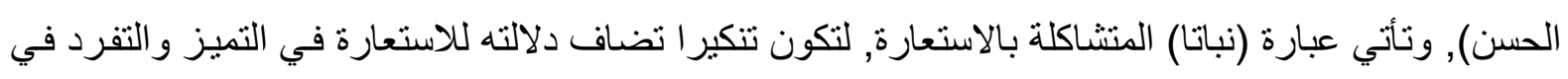
الخير و الحسن وكمال العناية بمريم عليها السـلام , وذلك من لطف الله سبحانه وتعـالى , وكمـال عنايته بعباده الأتقياء. 


\section{ثالثا :أثر التعريف والتنكير على دلالة الكناية}

أـ أثر التعريف على دلالة المجاز الكنائي: إن للتعريف أثر كبير في دلالة التعبير المجازي الكنائي , فقد يعطي

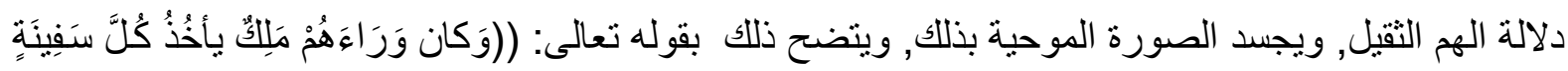

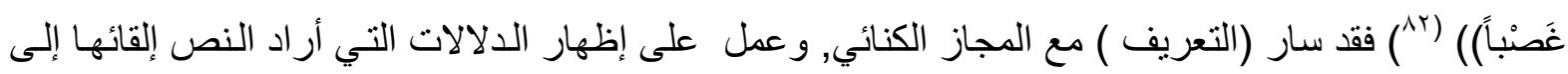
المتكلم , فالمجاز الكنائي( وكان ورائهم ) (كناية عن صفة الهم والثقل) و إن دلالة التقل و الحمل الثديد تحساكي

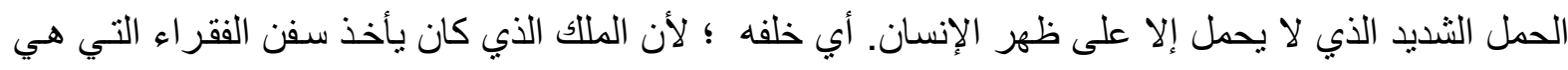

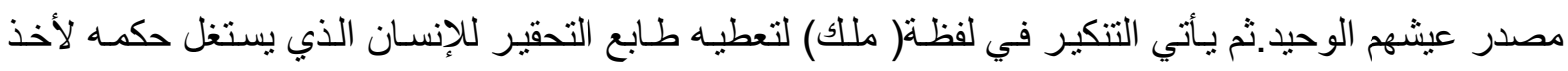
قوت الفقر اء, فهو (ملك) بـالتنكير دون تعظيم, ويأتي التكاتف بين الحذف و التعريف بالإضـافة( كل سفينة) و أصلها ( كل سفينة صـالحة) ويظهر أن وراء الحذف دلالة التعريف الذي يعطي طابع التكثير, ( الملك يأخذ السفينة الصالحة و غير الصـالحة), وهو في الحقيقة لا يأخذ إلا السفينة الصـالحة وبالتـالي أظهر النص القر آني شدة الجشع التي أحاطت بهذا الملك, وشدة الهلع, و الألم الذي أحساط بالفقراء ولذا فالبعد المجازي لعبارة) كان ورائهم ) قام (التعريف ) بإيضاح مفاصلها ورسم صورتها الموحية.

ويأتي التعريف ليترك أثره العميق على المجاز الكنائي, فينقله إلى الجانب التفخيمي, ومنـه قولـه تعالى في

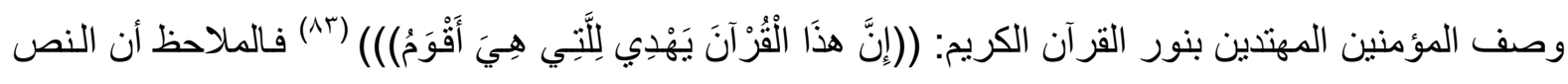

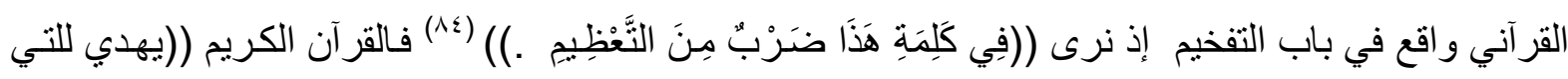

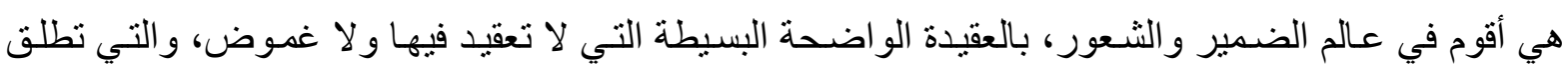
الروح من أثقال الو هم و الخر افة، وتطلق الطاقات البشرية الصـالحة للعمل و البناء، وتربط بين نواميس الكون الطبيعية ونـواميس الفطرة البشرية في تناستق واتسـاق.ويهدي للتي هي أقوم في التنسيق بين ظـاهر الإنسان

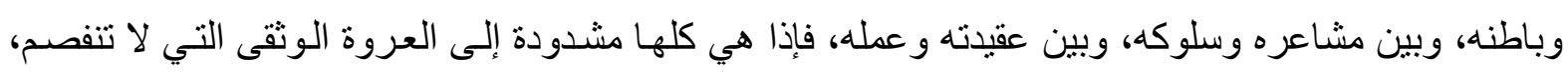

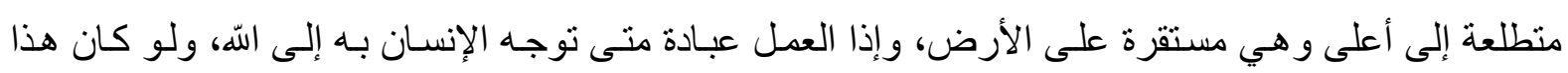

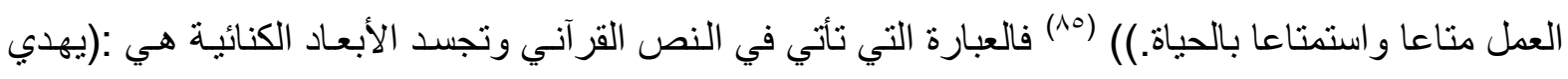
للتي هي أقوم) و (هي أقوم) كناية عن صفة الصلاح, ويبدو أن الطابع الكنائي الهجازي لله خاصية الاتساع , و الثمول, و الإحاطة, فالعبارة المتقدمة: ( هي أقوم) ممكن أن تكون: ( الصـلاح وتكون الربح وتكون الخـلاص من النـار و القرب من الجنة............الخ) وبهذا تتحمل كل الأشياء الحسنة التي تقود إلى رضـا الله سبحانه وتعالى , ويدخل التعريف من خـلال الاسم الموصـول( التي) ) و الضمير( هي) المرتبطلان بلفظ( أقوم) ليدخلا المجاز الكنائي في جو من التفخيم المتعاضد مـع مـا تركه المجاز من الاتسـاع النفعي, لتتعانق الدلالات سويا وتحول الطرح إلى المتلقي, مع إثارة خاصية التحفيز التي أظهرتها التداخلات الأسلوبية. إضافة لذلك فإن الاسم

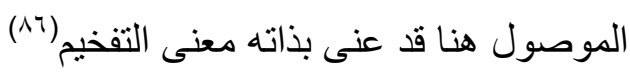

ويـخل أسم الاشـارة على المجاز القرآني فيعمل على إثارة حسالتين متقابلتين , أحدهما تثير التفخيم ,

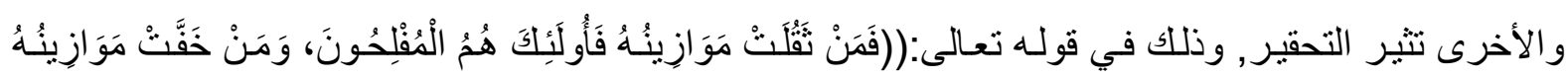




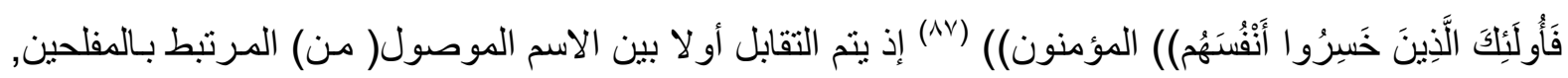
و الآخر المرتبط بالخاسرين, ويبدو أن عبارة ( من خفت موازينه) هي مجاز كنائي يبين الموصـوف المؤمن

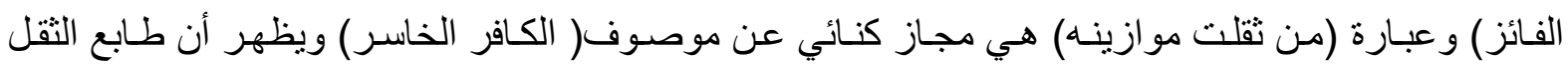
والخفة بالوزن جاء ليدخل الصورة في طابع الربح والخسارة الحسي المشاهد وجعله حقيقة, ويظهر أن التعريف من خلال اسم الإشارة المتقابل بين الطرفين( أولئك) ليعمل على خلق نمطين دلالين: فالأول: ( اسم الإشـارة) المتقدم الذي أعطى الإيحاء بالانتباه لهح, وثانيا: فقد خلق اسم الإشـارة خاصية التعظيم( للمؤمنين) وخاصية (التحقير) للكفار.

ويستخدم القرآن الكريم التعريف( بالاسم الموصول), ليتشارك مع الكناية في خلق دلالة تبتعد عن التصريح

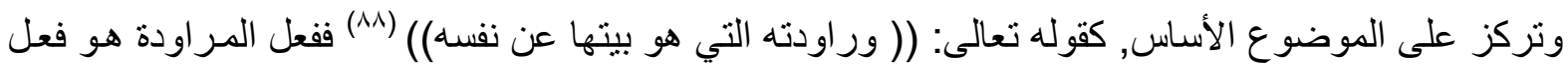
إيحائي يوحي بالفعل المحرم الذي تنزه النبي يوسف (عليه السـلام )عنـه, وتدخل عبـارة( التي هو بيتها) لتمثل امر أة العزيز( زليخا) التي لم يذكر ها النص القرآني, وإنمـا كنى عنها بعبارة: (التي هو في بيتها), و إن لفظة:

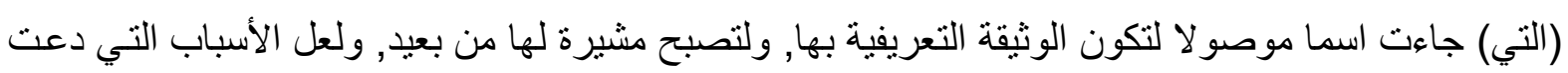

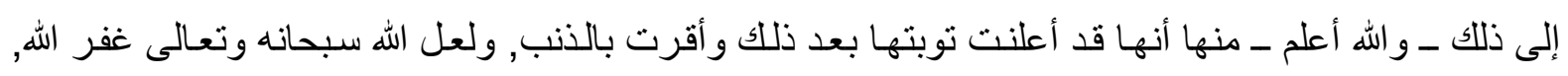
فجاء الأمر بالإيحاء الذي لازم الكناية والتعريف.

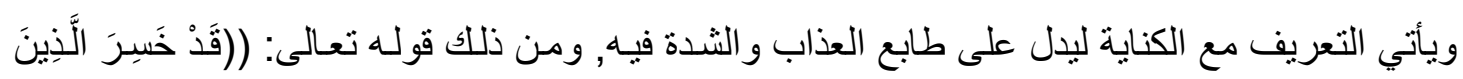

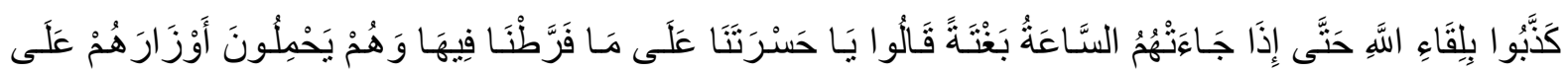

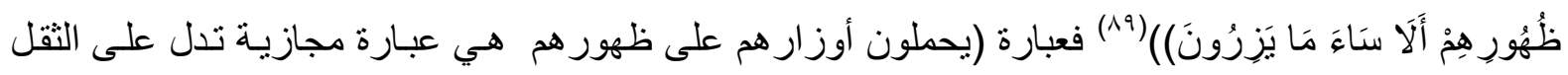
و الكثرة وربما المضمون ((هو - و اللَّ أعلم - على التمثيل، وليس على التحقيق، وهو يحتمل وجهين: يحتمل: أنه

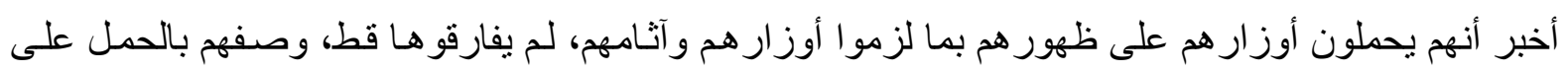

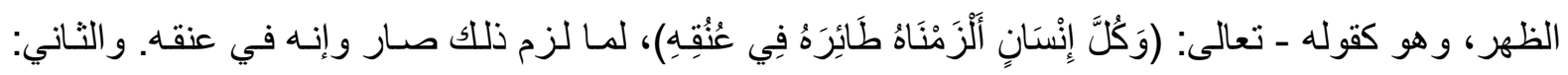

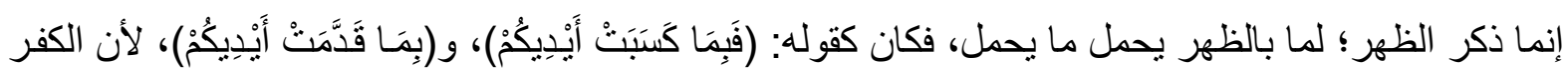
لا يكتسب بالأيدي و لا يقدم بها، لكن اكتساب الثيء وتقديمه لهـا كان باليد ذكر اكتسـاب اليد وتقديمها. وكقوله:

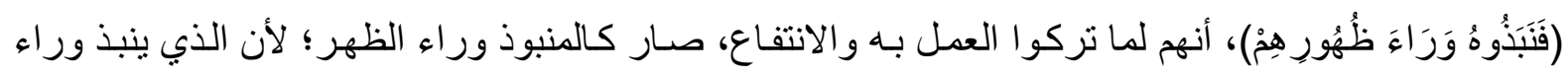

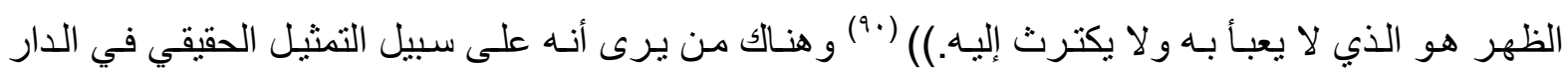
الآخرة ((وذلك أن الكافر إذا بعث في الآخرة أتاه عمله الخبيث في صورة حبشي أشوه منتن الريح كريـه المنظر فيقول له الكافر: من أنت؟ فيقول: أنا عملك الخبيث قد كنت أحملك في الدنيا بالثـهوات و اللذات! فاحملني اليوم. فئ. فيقول: وكيف أطيق حملك؟ فيقول: كما حملتك، فيركب ظهره،)((9) لكن الحقيقة أنها ضاربة في المجاز؛ ل لأن: (الأوزار جمع وزر وهو في الأصل الحمل الثقيل يقال وزرتـه أي حملته ثقيلا ومنهـه وزير الملك لأنه يتحمل

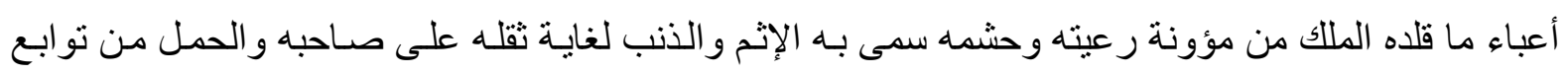
الأعيان الكثفية لا من عوارض المعاني فلا يوصف به العرض الا على سبيل التمثيل والتشبيه وذكر الظهور 
كذكر الأيدي في قوله تعالى فَبِما كَسَبَتْ أَيْدِيكُمْ فان المعتاد حمل الأثقال على الظهور)( (rو) ورغم ما تقدم فالآية

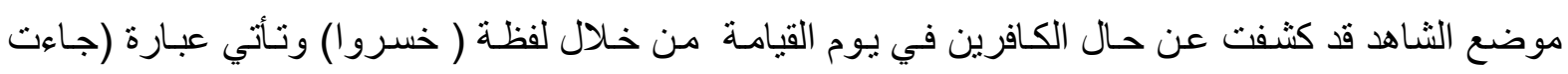
الساعة ) لتبين (الكناية عن موصوف) و التي تمثل (يوم القيامـة) وقد جـاء الإيحاء بالكنايـة ليعطي النص طابعا تخويفيا ؛ إذ أن لفظة الساعة تمثل البعد التخويفي الأقوى؛ من خلال التجسيد لهول ذلك اليوم, ويدخل التعريف في لفظة( الساعة) التي تتضمن الكناية لتبين الحضور , والمعرفة الكاملة بها لينكثف طلابع التخويف الأكبر من خلال المعرفة التامـة, ويظهر الطرح المجازي الثاني في عبارة (يحملون أوزارهم فوق ظهور هم) ليبين الإيحاء المجازي فهم لا يحملون الذنوب فوق ظهورهم و إنما يحملون أوزارهم في نفوسهم, و إنمـا جـاء المجاز

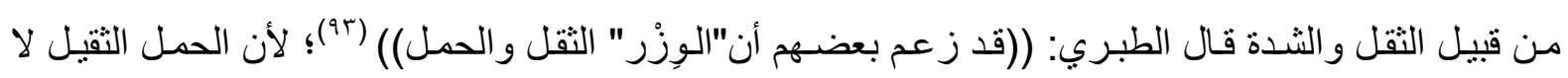
يحمل إلا على الظهر, ويبدو ( أسلوب التعريف ) في المجاز من خـلال الضمير (هم) العائد على المذنبين في(ظهور هم , أوزارهم) معرفا, ليبين الاختصاص, فهم لا يحملون (أوزارا) على ( ظهور) بالتتكير, و إنما جاء في باب التعريف( على ظهور هم ) ليبين الماهية التي تتبطن الحمل و التقريع والاختصـاص , فذنوبهم - هم وليس غير هم - هي التي أعطت الحمل و الثقل والثـدة على ظهور هم, وذلك ذنبهم الذي اقترفوه فاستحقو ابـه العذاب.

ويأتي التعريف بالاسم الموصول ليكثف الإبهام الذي ربما قد يحيط بالطرح المجازي الكنائي, كما في قوله

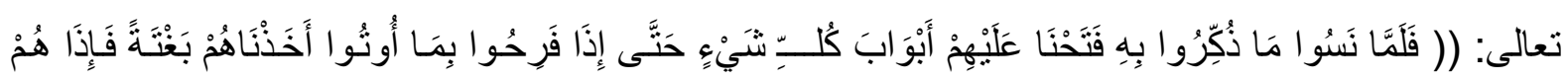

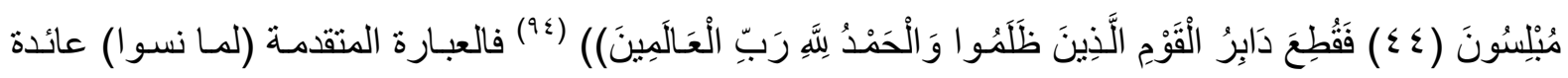
إلى غائب مجهول , غير معروف, و وتدخل صورة العذاب( قطع دابر القوم) مسبوقة بموجبات العذاب وهي: (نسوا ماذكروا به, فرحوا بما أؤنوا), ثم إن الصورة الكنائية المتقدمة (قطع دابر) التي تعني صفة الهلاك التام, جاء بعدها متصدلا عبارة( الذين ظلموا) ليبين المشمولين بشدة العقاب المتقدم وهم الذين أخذوا بالعذاب (بغتـة) لتظهر العدالة الربانية, والحكمة, والعلو؛ بدلالة الجملة الخبريـة (الحمد لله رب العـالمين) الذي يقمع الجبارين, ويستحق الحمد, و الثناء جل سبحانه وتعالى.

ويأتي التعريف بالإضافة مع الكناية ليشكلا معا وسيلة فاعلة قادرة على إيصـال دلالـة التذكير المززوجة

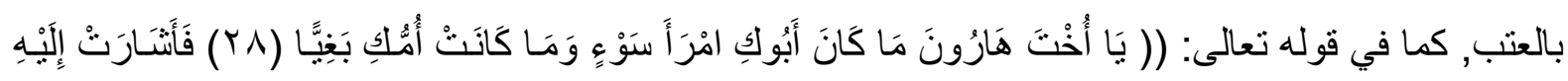

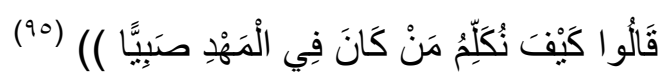
يتقدم النداء (يا) للتنبيه للأمر المهم, وتدخل عبارة (أخت هارون) كناية عن صفة العفة التي أحاطت بمريم

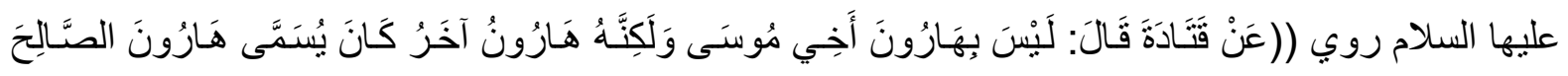

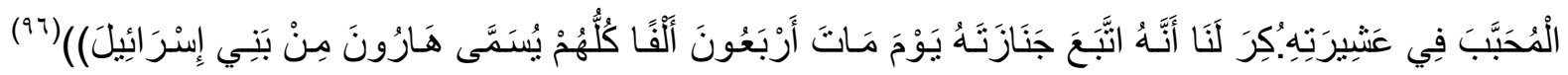
ويظهر أن أسلوب التعريف في الكنايـة (أخت هـارون) قد جـاء ليعرف مريم عليهـا السـلام من خـلال ربطهـا بهارون عليه السلام من خلال لفظة (أخت) التي هي الأخرى كناية عن القرب منه ومن أخلاقه ومشـابهتها لـه,, 
وبهذا يكون النص داخلا في العتب وباب الاندهاش من الفعل المتقدم ولهذا جاءت عبارة(مَا كَانَ أَبُوكِ امْرَأَ سَوٍْء

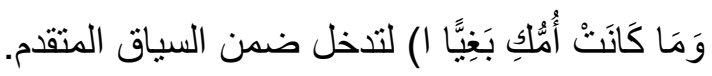

ويأتي التعريف متسـاوقا مـع المجـاز الكنائي كضرورة ملحـة لتبيان غايـة مهمـة, كتوضيح السـرعة و الثـدة

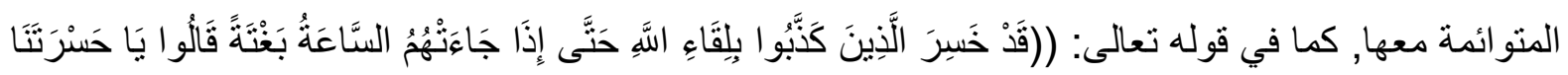

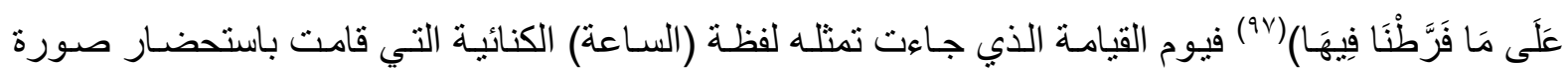
العذاب, و ويبدو أن السرعة والقوة جاءت من اتحساد الكناية مسع التعريف, فالسـاعة جاءت (بغتة) وتلك سر عة موحية بالقوة, وتعريف اللفظة المتقدمة(الساعة) قد أركز ها في باب التفخيم والتعظيم. ويأتي الضمير التعريفي مرتبطا بلفظ الكناية, ليدل على الخسران المحيط بالموصوف دون سواه مبالغـة بالتحذير , كمـا في قوله تعـالى:

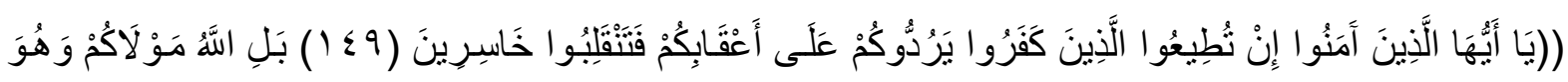

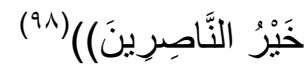

إن صورة الانقلاب التي أظهرتها الصـورة الكنائيسة المجازيـة تنقلبو ا على أعقابكم) أتت لتوحي بصفة

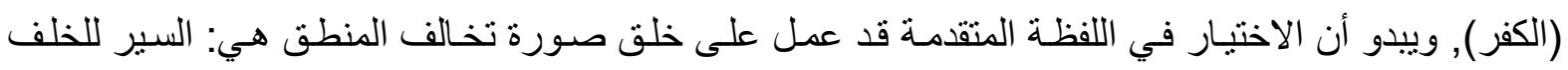
و الانقلاب, الموحية بالخسران لقوله تعالى: (تصبحوا خاسرين), والظـاهر أن الضمير التعريفي( كم ) المرتبط

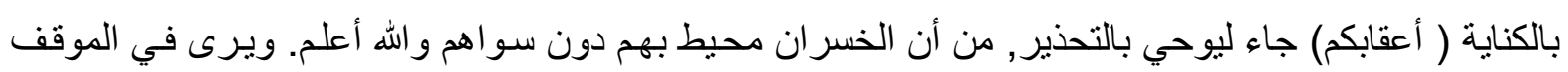
التي تحتاج إلى الثبات, و التميز , و التفرد, يأتي أسلوب (التعريف) ففي النص القرآني الآتي: يتشكل أسلوب التعريف من الضمير المنفصل الدال على الظهور ومتبو عا بتعريف الإضـافة؛ ليقوي من أثر الثبات المطروح مع المجاز الكنائي, كمـا في قول الحواريين في خطابهم جو ابـا على طلب النصرة لله من عسى عليه السـلام

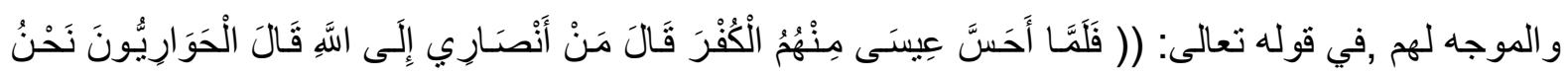

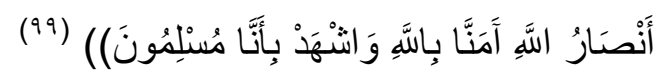

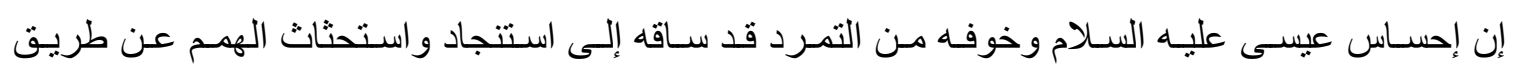
الاستفهام (من أنصساري إلى الله) الذي كان استفهاما مجازيـا خارجـا لحث الهمم والاستتجاد, ويبدو أن خطـاب

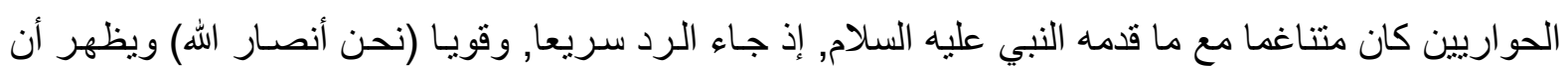
العبارة المنقدمـة هي: عبارة كنائية توحي بصفة التفاني التام في نصـرة الدين, و الملاحظ أن المد المجازي الكنائي المتقدم (نحن أنصار الله) قد أعطى إيحاءً أكبر مما تعطيه الحقيقة, ويأتي الضمير الذي يحمل التعريف (نحن) الدال على الحواريين ليشكل السطوع الواضـح القائم على الظهور وعدم الاختفاء أو التردد الموحى التهى بالتفاني ليتساوق مع المعنى المجازي الكنائي, ثم إن الرفد التعريفي الآخر( أنصسار الله) جاء هو الآخر ليحمل

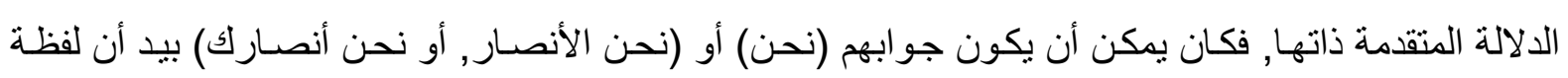
(أنصـار الله ) المتقدمة جـاءت منغرسـة في مفصل الدلالـة الدالة على التفاني مـع الله سبحانه وتعـالى والإيمـان الر اسخ بالجز اء والنصرة, ويمكن رصد الدلالة من خلال ما يأتي: ا ـ نحنـ فيها قوة ولكن ليست كبيرة لوجود محذوف مقدر...نحن أنصار الله... وفيها ضعف وربما تراخي. 


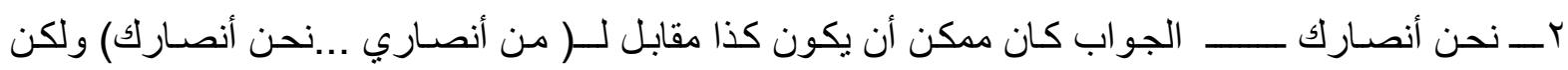

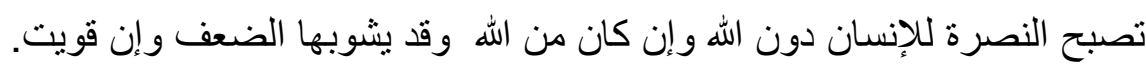
أقوى الدلالات ؛ لأن النصرة ارتبطت بالله سبحانه وتعالى وله. بـ نحن أنصار الله

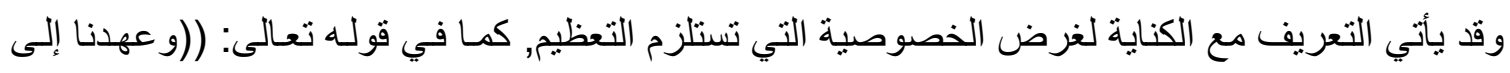

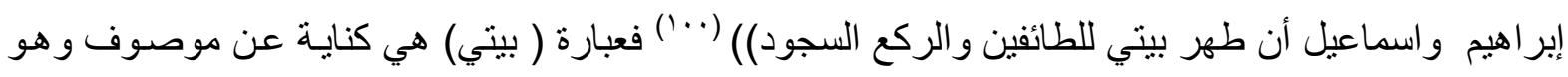

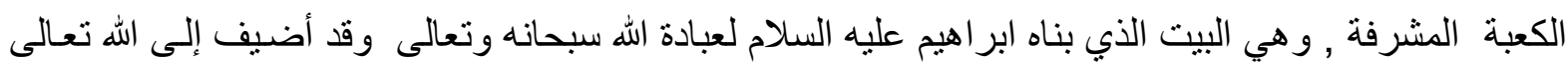

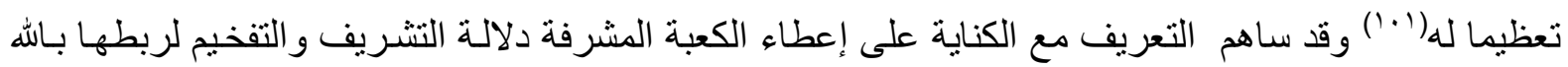

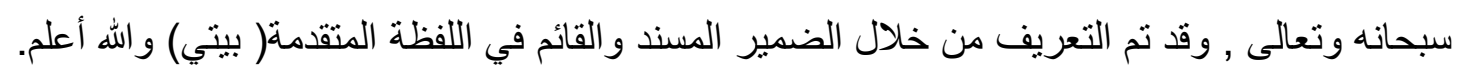
ب ـ أثر التنكير في دلالة المجاز الكنائي: باتٔي التنكير في النص القرآني مر ادفا للكناية ليعمل معها على إثارة

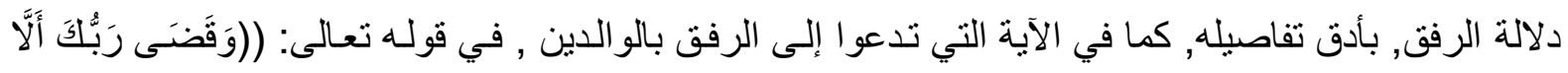

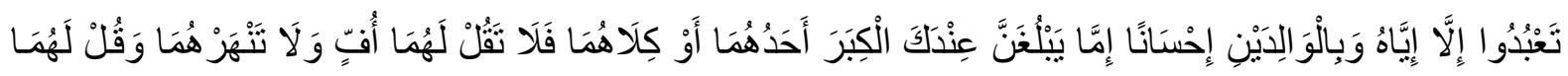

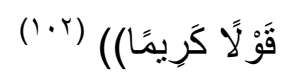
النص القراني المتقدم يحشد كافة العبارات والألفاظ من أجل تسليط الضو و والحث على الرفق بالو الدين

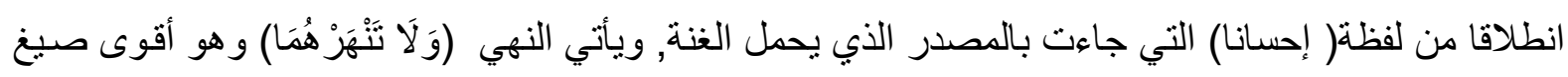

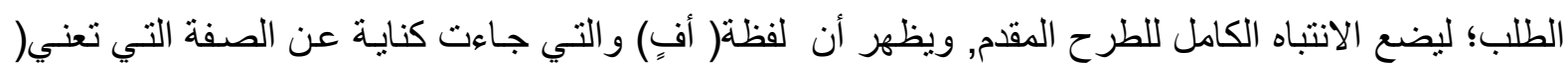

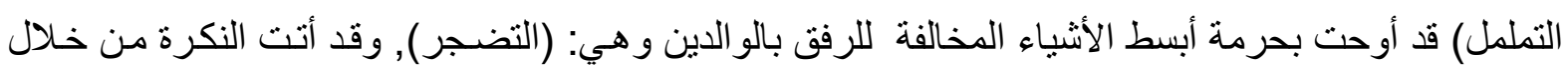

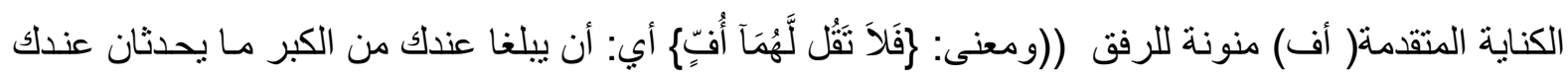

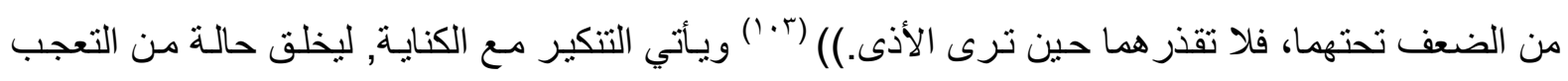

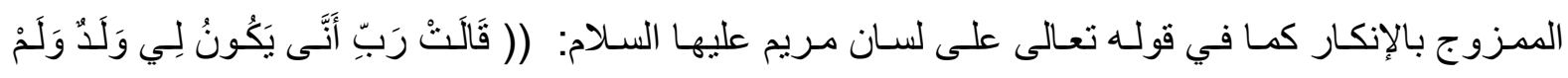

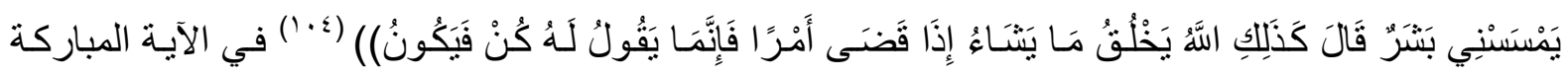

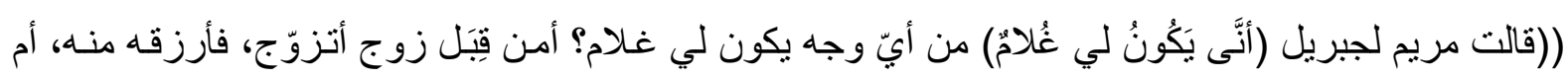

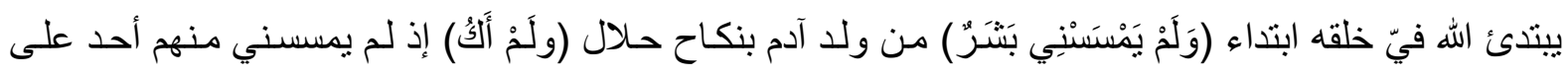

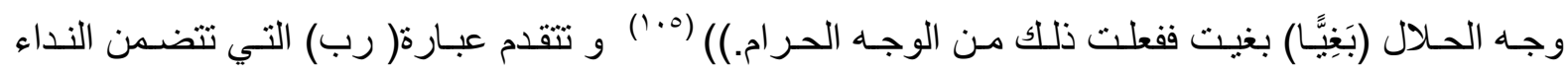

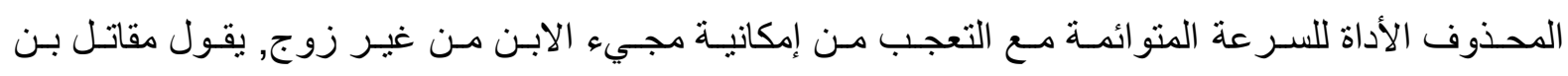

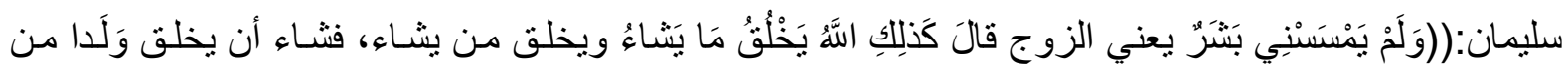

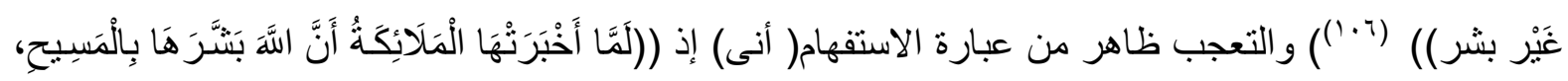

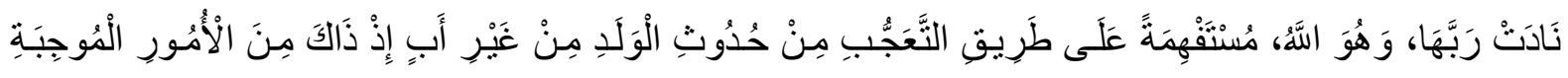

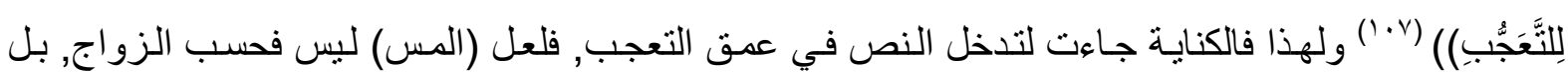

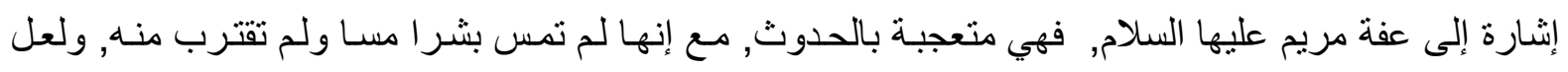


التتكير في ( بشـرا) جـاء ليتسـاوق مـع التعجب المتقدم فلفظـة( بشر) دخلت في كل الجنس البشري أصسره, وأعظمه مكانة دون استثناء .. و الله أعلم

\section{رابعا :أثر التعريف والتنكير على دلالة المجاز المرسل:}

وقبل الدخول فيه فلابد من المرور به وهو مجاز لغوي يتميز لا يقوم على الحقيقة مثله مثل الاستعارة بيد

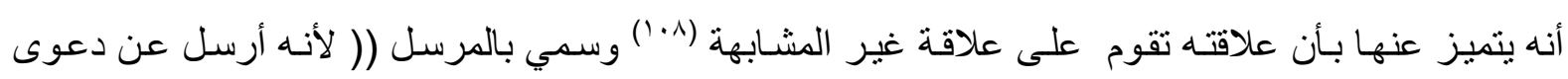
الاتحاد المعتبرة في الاستعارة إذ ليست العلاقة بين المعنيين المشابهة حتى يدعى اتحاده)(9 (1) و إنما يقوم معناه

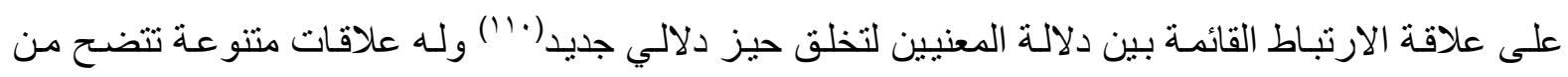

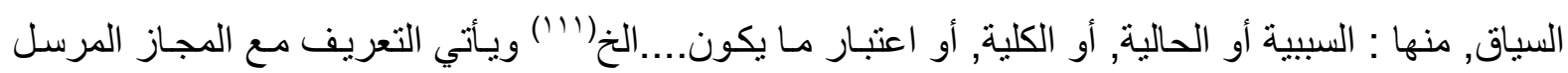

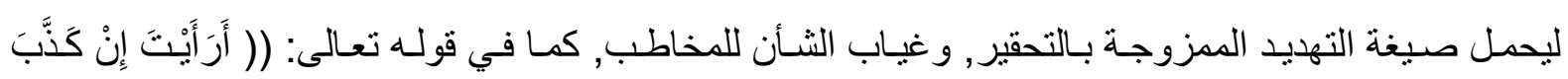

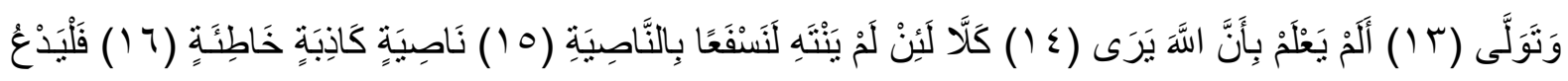

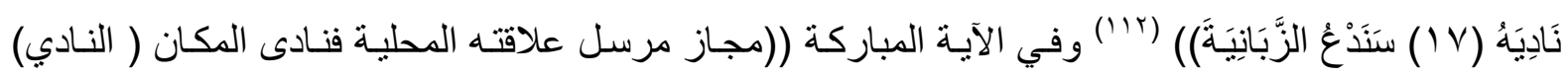

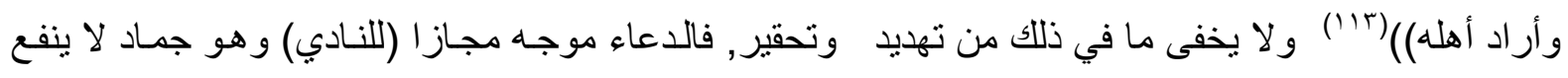
و لا يعين , وبالتالي غياب النفعية وغياب الناصر , ليتآزر المضمون المجـازي نفسـه مـع آليـة التعريف التي جـاء

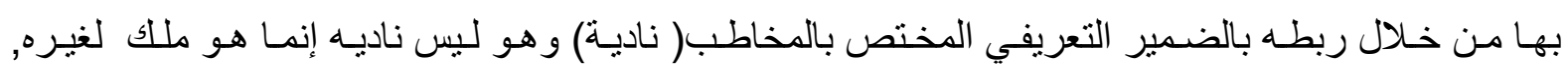
لتتصاعد لهجة التهديد بتحمل العو اقب الوخمية وكأنه مسؤول عن كل مـا اقترف بالنـادي من آثام, والله أعلم ويأتي التعريف بالإضـافة , ليبين عمق الحالـة, في تبيـان رحمـة الله الموجبة للجنـة, لتسير مـع دلالـة المجـاز

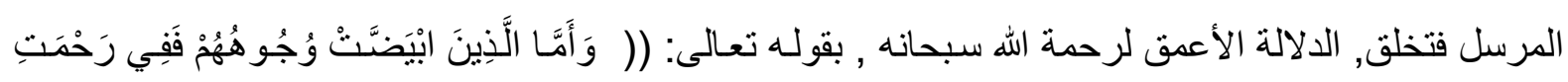

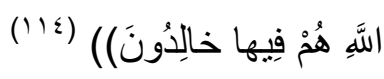
فالنص القر آني فيه مجاز مرسل في عبارة (رحمة الله) ((و المقصود ب(رَخْمَتِِ اللَّهِ) جنّة الله، والجنّة هي المحلّ الذي تحلّ فيه رحمة الله، ففي الآية مجاز مرسل، إذ ذكرت الآية الحالّ (الرحمـة) وأرادت المحلّ (الجنّة)

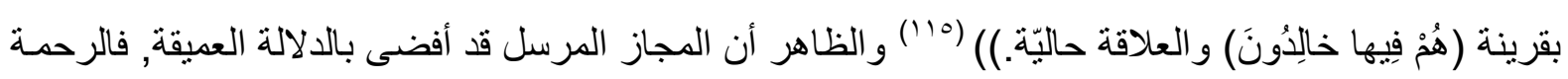

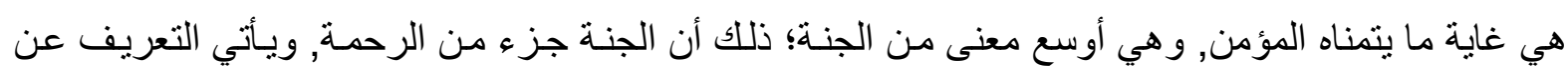

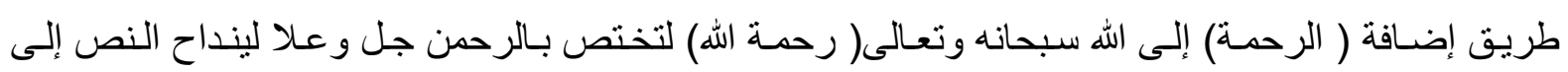
رحمة تفوق الوصف فهي رحمة الكريم العظيم. ويدخل الاسم معرفا بالضمبر مع المجاز المرسل , ليحمل دلالية

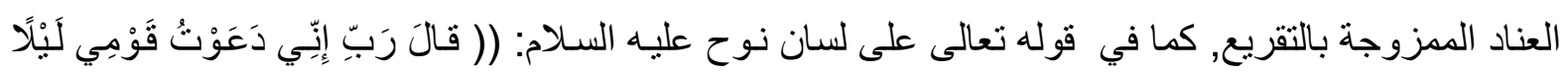

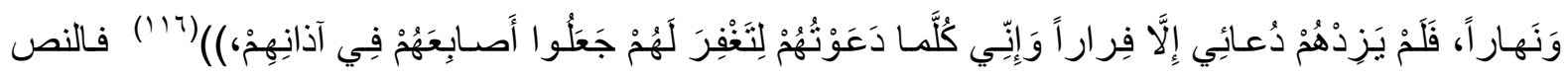
القر آني قائم في دلالته على المجاز المرسل ((فالكلمة موضع المجاز في هذه الآية الكريمة هي لأصسابعهمه فقد

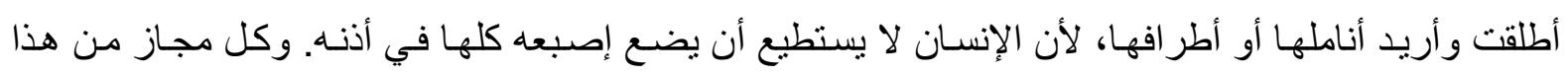

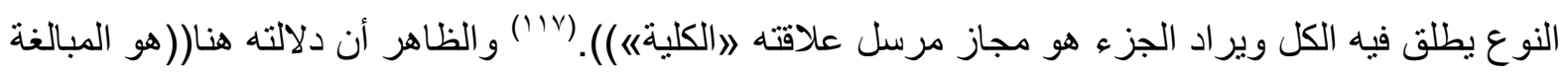

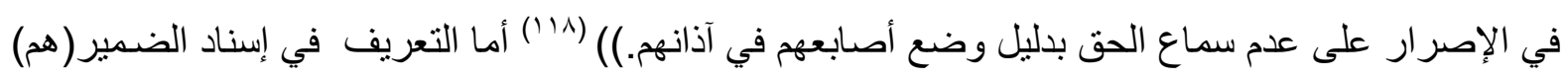


( للأصابع) في ( أصابعهم) فقد حمل الجانب التهديدي الحامل للتقريع فالأصسابع لهم والعمل العنادي منبثق منهم, و هذا ما يؤيد استحقاقهم العذاب و الله العالم.

ويؤثر التنكير على المجاز المرسل, فيعملان معا على الدلالة المر اد رصدها بدقة, كما في قوله تعالى:

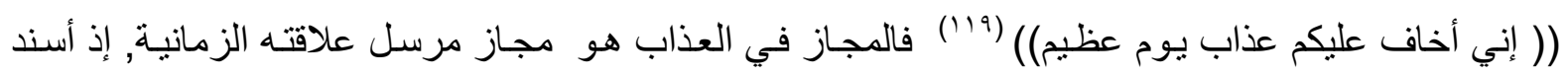

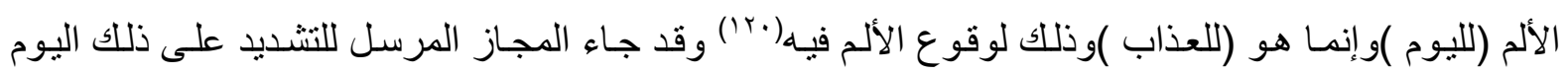

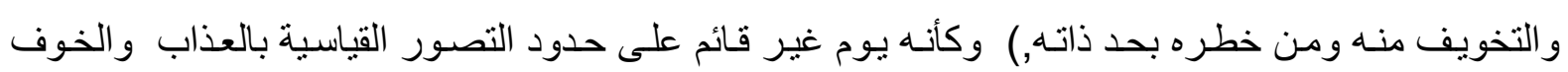

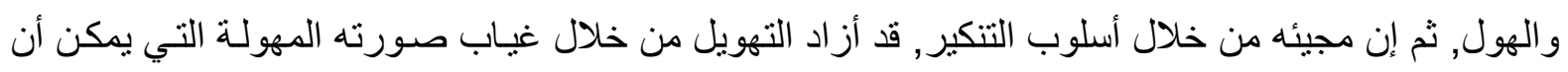

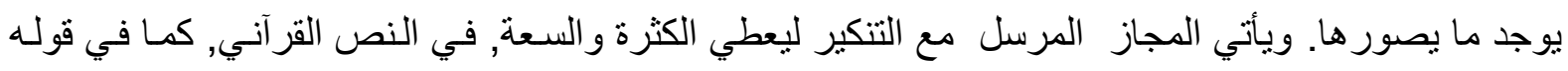

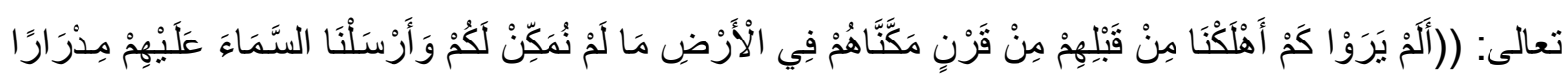

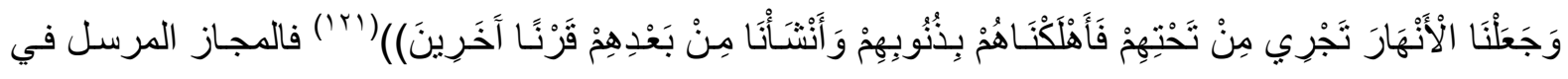

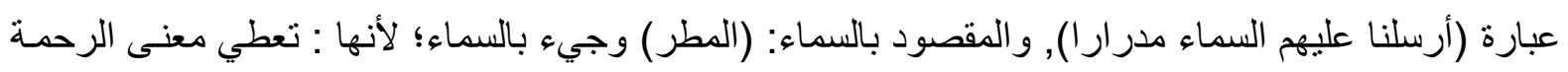

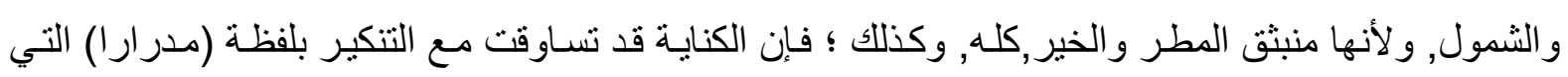
عنت هي الأخرى السعة والاستمر ار.

وقد يجتمع التعريف والتنكير معا؛ ليرفدا دلالـة الهجاز المرسل القرآني عن طريق السياقات الأسلوبية

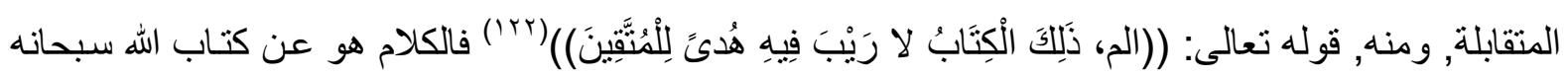

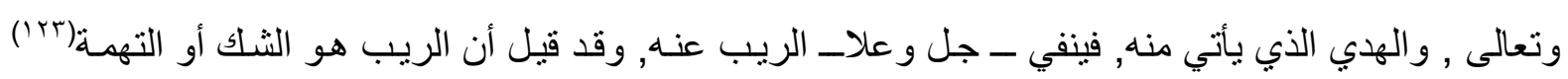

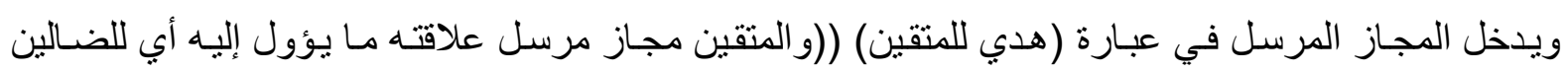

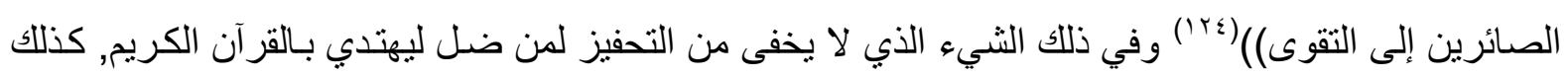

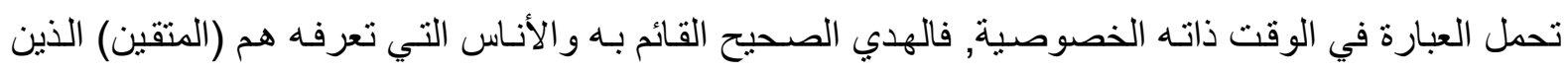

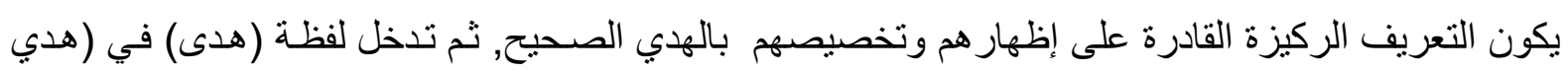

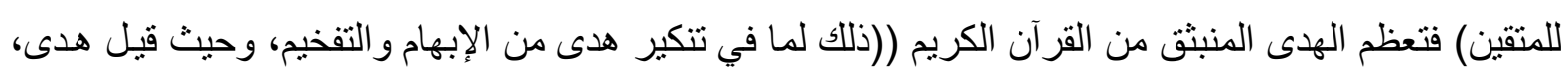

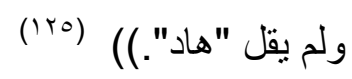

\section{وفي ختام البحث فلابد هن تقديم أهم النتائج التي توصل إليها البحث}

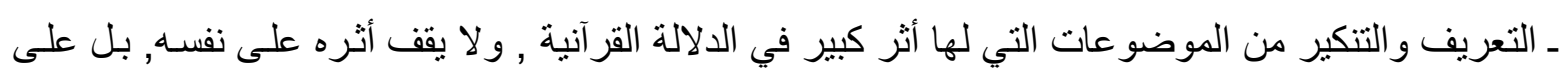

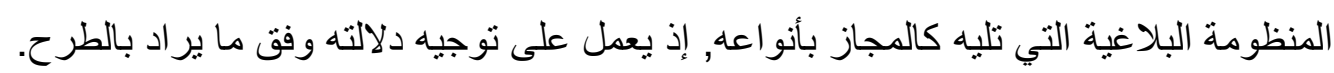

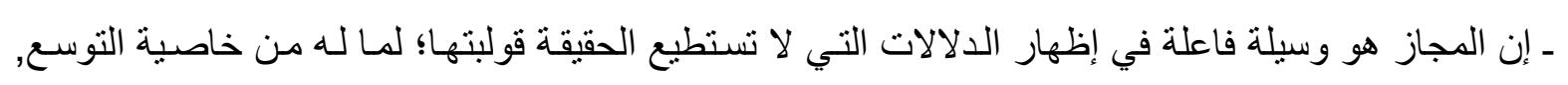

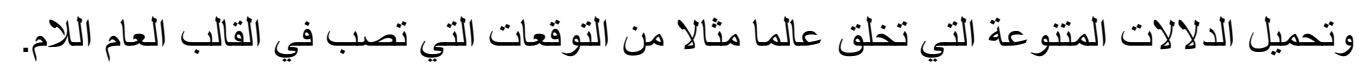
ـ إن التعريف و التنكير وفق آلية التأثير على المجاز القر آني يقوم على خلق دلالات متنو عة منها: التي تقوم

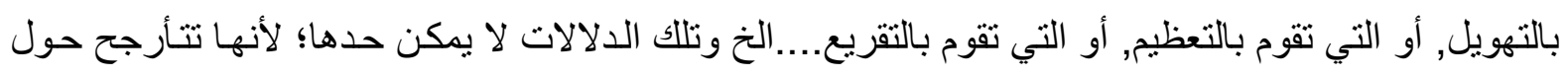

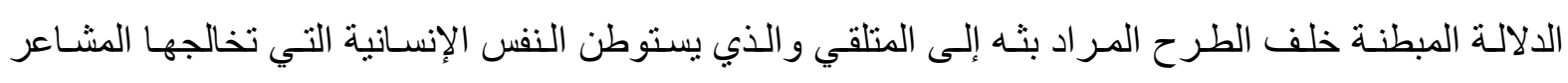


المتنو عة, التي تتراوح بين الضعف والقوة, فيكون التكاتف بين أسلوبية التعريف والتتكير والمجاز هي الطريقة الوحيدة القادرة على استيعاب مفاصلها ولم أطر ها.

- إن هناك دقة في الربط بين المجاز و التعريف و التنكير , فمرة نرى أن العبارة المجازيـة لا يصلح لتقويتها ورصد أثرها سوى التعريف, ومرة أخرى يصبح التعريف عاجز ا عن رصد أثر المجاز القرآني, فيسطع التنكير فيكون الوسيلة المثلى القادرة على استجلاء أبعاد الدلالة بكل مفاصلها. ــ كانت سطوة أسلوب التعريف والتنكير كبيرة على أسلوب التشبيه, فقد عمل التعريف كثير ا على تفخيم التشبيه, وربما عمل التعريف على إركاز الدلالة الحسية المقابلة للمعنويـة, وجاء ذلك كثيرا , في بـاب التوبيخ و التقريع, وقد انطبق ذلك الأمر على الاستعارة و الكناية. ــ للتنكير خاصية كبيرة على تقوية الوصف المجازي التشبيهي و الاستعاري و الكنائي, خاصة ذلك الذي يسعى لخلق صورة تفوق التصور, كالتخويف , و التهويل, والتعجيب.

الهوامش

(') الطر از المنضمن لأسرار البلاغة و علوم حقائق الإعجاز , السيد الإمـام يحي بن حمزة بن ابر اهيم العلوي اليمني, مر اجعة وضبط وتدقيق

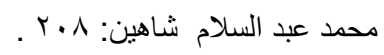

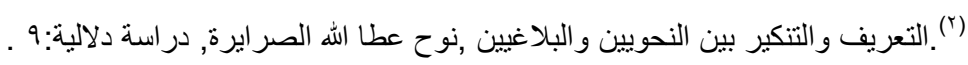

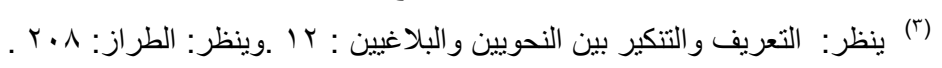

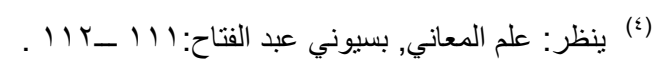

(o) : ينظر : شرح التسهيل , تسهيل الفوائد وتكميل المقاصد, جمال الدين بن عبد الله ابن مالك الطائي الاندلسي, تحقيق: محمد عبد القادر عطا

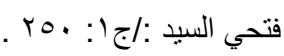

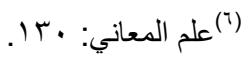

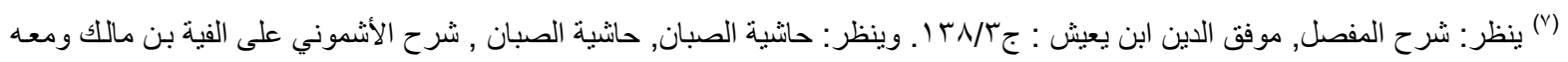

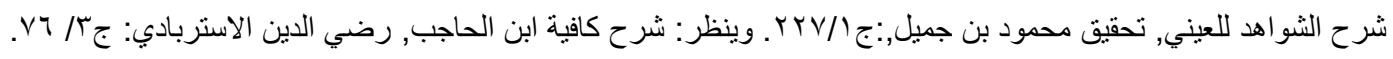

$$
\text { (ه) }
$$

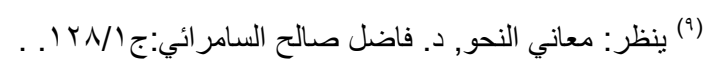

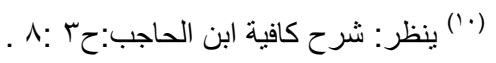

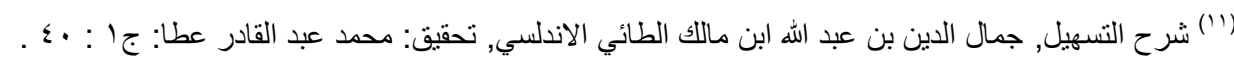

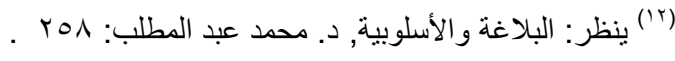

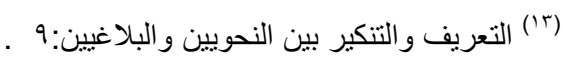

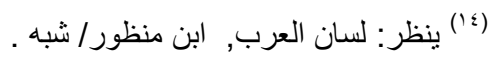

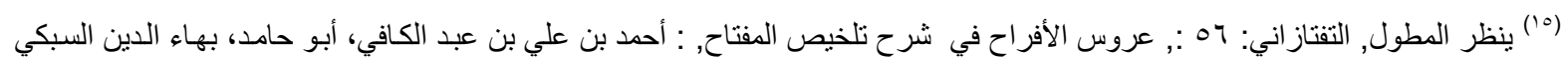

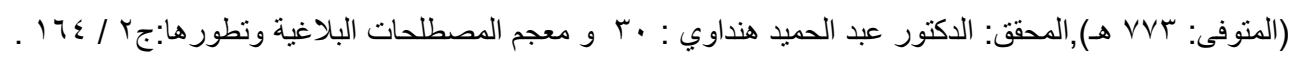

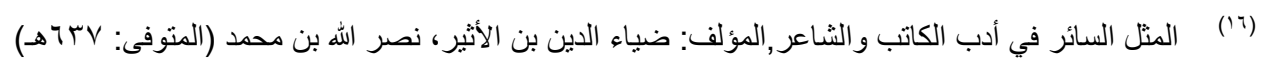

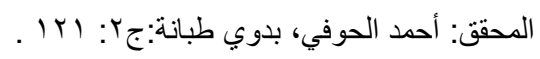

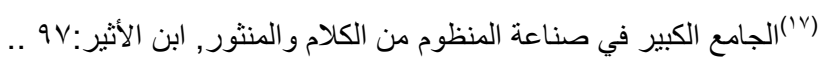

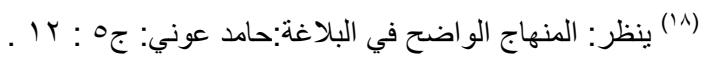


(9) ألجامع الكبير في صناعة المنظوم من الكلام والمنثور , نصر الله بن محمد بن محمد بن عبد الكريم الثيباني، الجزري، أبو الفتح، ضياء

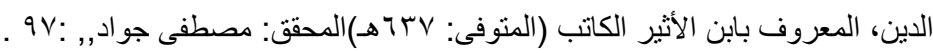

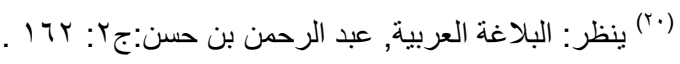

$$
\begin{aligned}
& \text { (r) سورة الجمعة /(r) }
\end{aligned}
$$

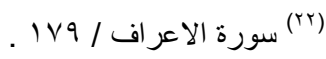

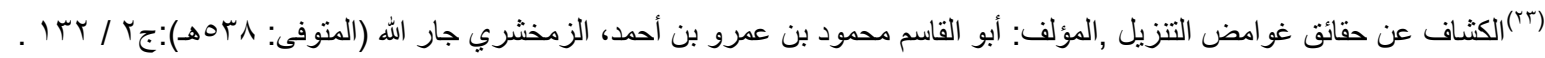

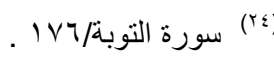

$$
\begin{aligned}
& \text { سورة هودم/ (ro) }
\end{aligned}
$$

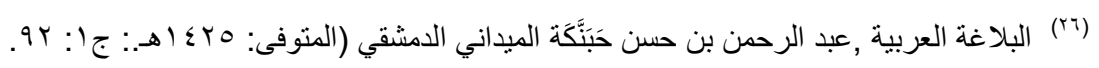

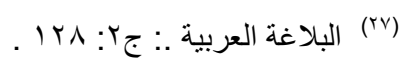

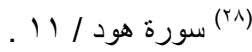

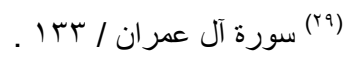

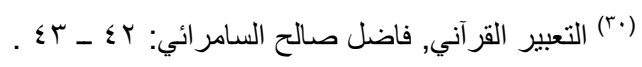

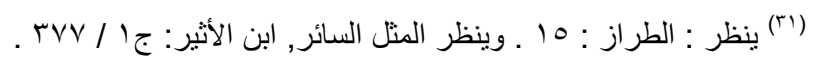

. V/

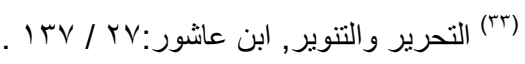

(r乞)

V V

.

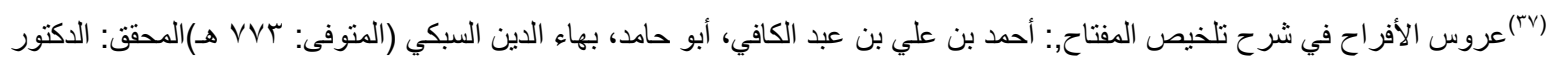

$$
\begin{aligned}
& \text { عبد الحميد هنداوي: جץ : .A . } \\
& \text { سورة البقرة/ (ب^) }
\end{aligned}
$$

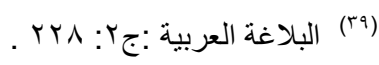

(.•) البيان و التبيين , عمرو بن بحر بن محبوب الكناني بالو لاء، الليثي، أبو عثمان، الثهير بالجاحظ (المنوفى:

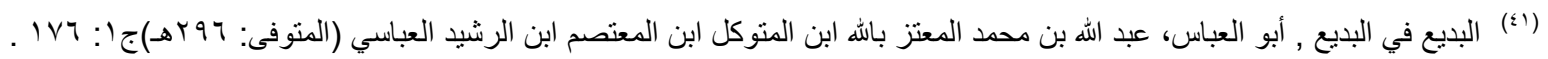

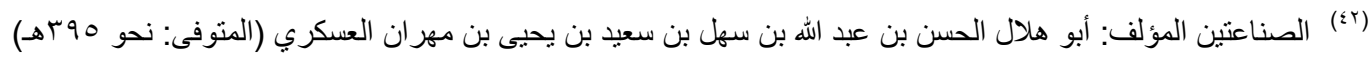

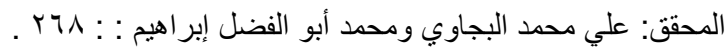

(rاء) أسرار البلاغة, المؤلف: أبو بكر عبد القاهر بن عبد الرحمن بن محمد الفارسي الأصل، الجرجاني الدار (المتوفى: (اكگهـ)

$$
\text { قر أه و علق عليه: محمود محمد شاكر: • r. }
$$

(؛؛) الإيضاح في علوم البلاغة ,: محمد بن عبد الرحمن بن عمر، أبو المعالي، جلال الدين القزويني الثافعي، المعروف بخطيب دمشق

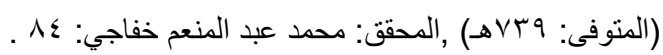

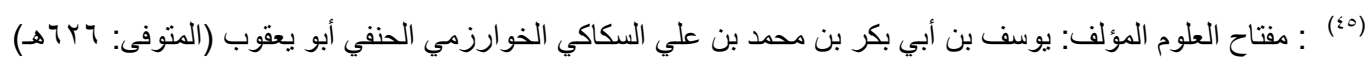

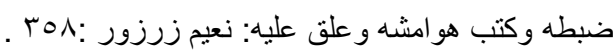

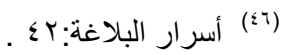

مV : ينظر: الطراز

(ఓ^)

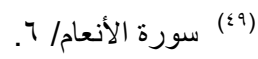

(0.0 القيامة الكبرى, عمر بن سليمان بن عبد الله الأشقر العتيبي:191. 
(ان) تفسير القرآن العظيم المؤلف: أبو الفداء إسماعيل بن عمر بن كثير القرشي البصري الدمشقي (المتوفى: عVVهـ) المحقق: سامي بن محمد سلامة:جr:

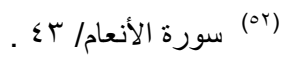
. أسورة التوبة/ 9 (or)

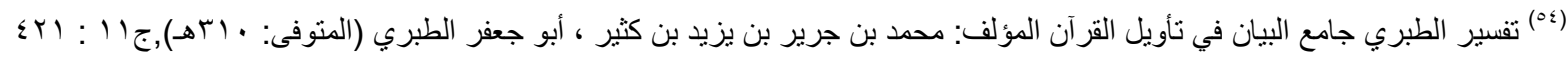

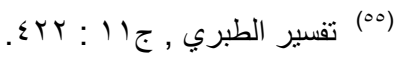

$$
\begin{aligned}
& \text { (10 (0) }
\end{aligned}
$$

(الجامع الأحكام القرآن = تفسير القرطبي , أبو عبد الله محمد بن أحمد بن أبي بكر بن فرح الأنصاري الخزرجي شمس الدين القرطبي

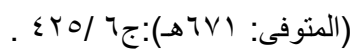

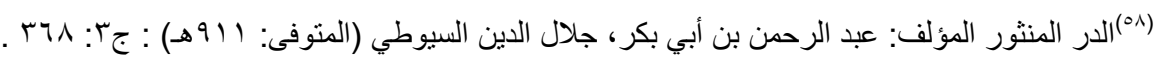

$$
\text { . سورة الأنعام/ } 9 \text { ؟ }
$$

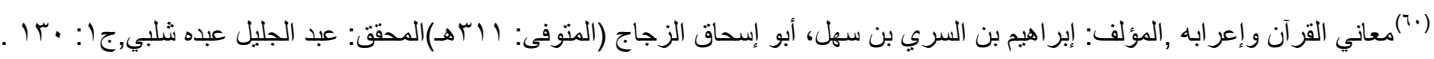

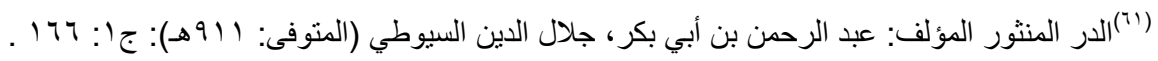

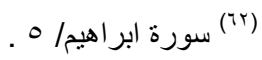

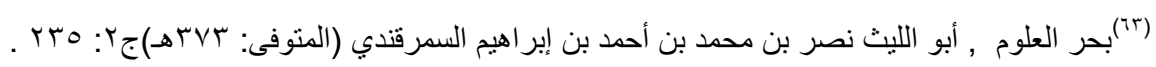

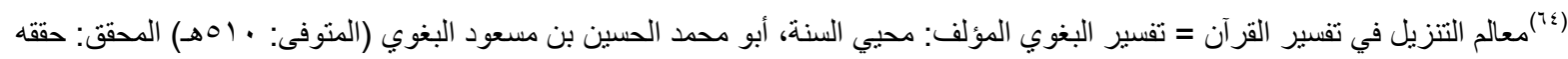

وخرج أحاديثه محمد عبد الله النمر - عثمان جمعة ضميرية - سليمان مسلم الحرش: جع: هبرئ.

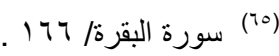

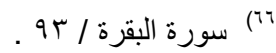

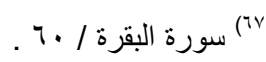

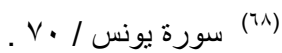

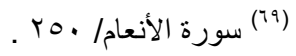

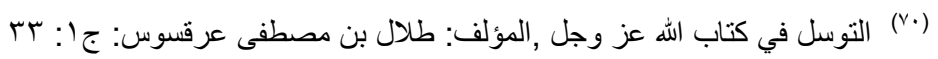

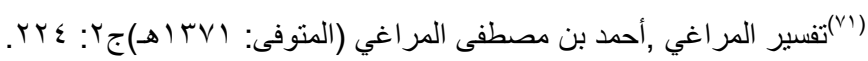

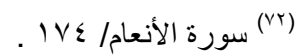

(Vץr)

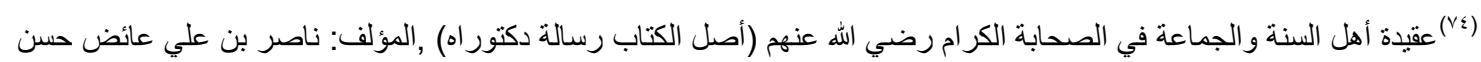

الشيخ,:ج): . 19.

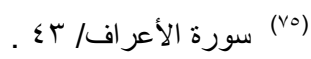

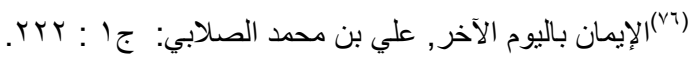

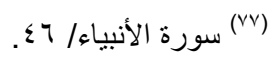

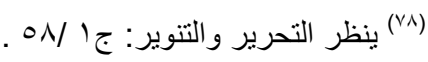

. سورة هودد/ (19)

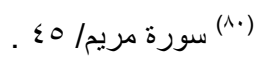

سورة (ㅅ)

. Vq/

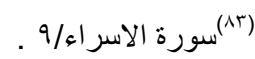

(اء)(مفاتيح الغيب = التفسير الكبير , أبو عبد الله محمد بن عمر بن الحسن بن الحسين التيمي الرازي الملقب بفخر الدين الرازي خطيب الري ، الري

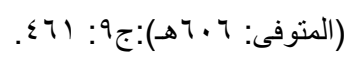

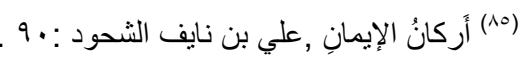


ينظر : التعريف والتنكير عند النحويين و البلاغيين: بهو

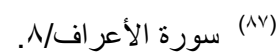

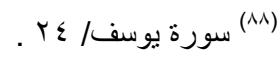

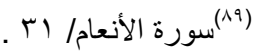

(•9): تفسير الماتريدي (تأويلات أهل السنة) المؤلف: محمد بن محمد بن محمود، أبو منصور الماتريدي (المتوفى: بستهـ)

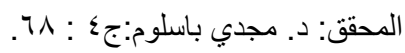

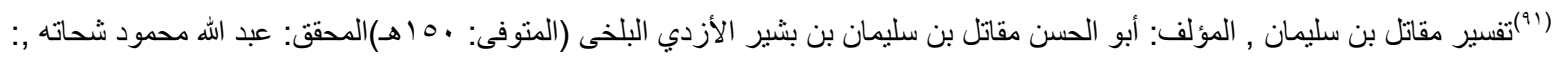

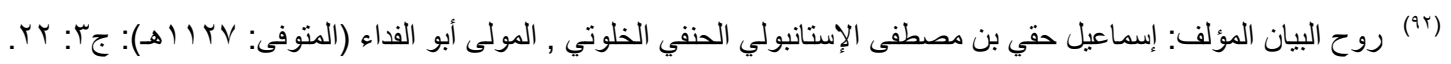

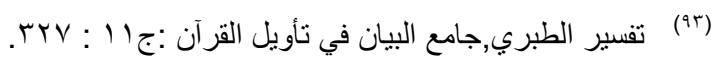

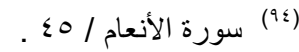

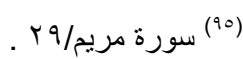

(T9"تفسير يحيى بن سلام المؤلف: يحيى بن سلام بن أبي ثعلبة، التيمي بالو لاء، من تيم ربيعة، البصري ثم الإفريقي القيرواني (المتوفى:

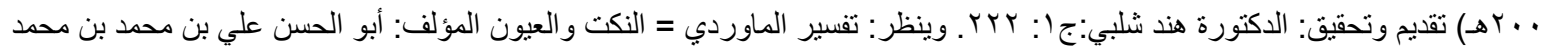

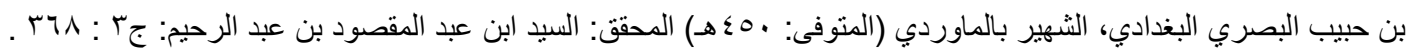

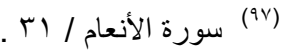

آ سورة آل عمران / (9^)

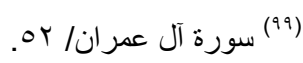

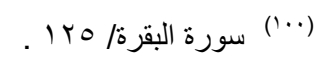

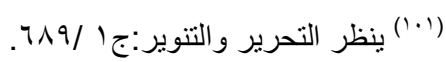

(1.r)

(r) (1) الهداية إلى بلوغ النهاية في علم معاني القرآن وتفسيره، و أحكامه، وجمل من فنون علومه ,المؤلف: أبو محمد مكي بن أبي طالب حَمّوش بن

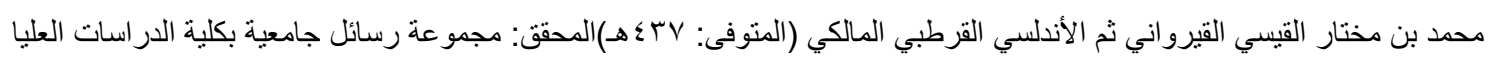

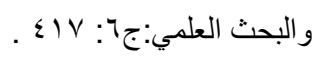

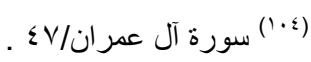

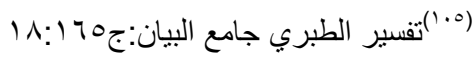

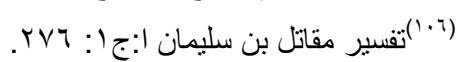

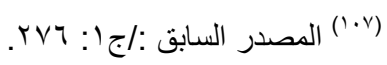

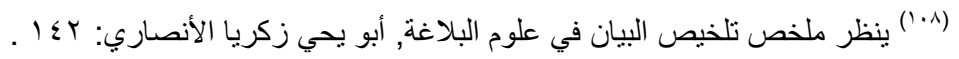

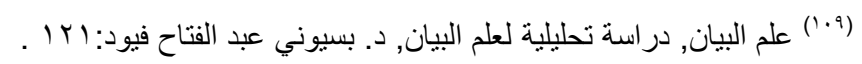

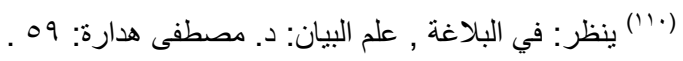

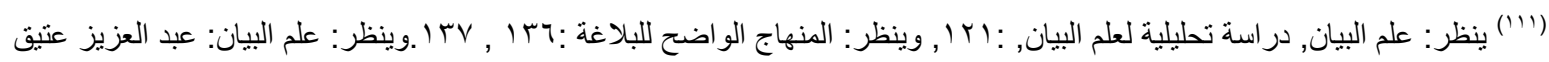

$$
\begin{aligned}
& \text { 109: }
\end{aligned}
$$

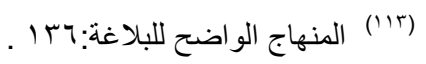

$$
\begin{aligned}
& \text { (1) }
\end{aligned}
$$

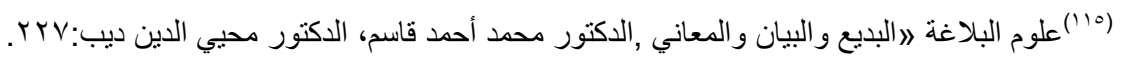

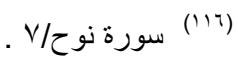

$$
\begin{aligned}
& \text { (I'V) }
\end{aligned}
$$




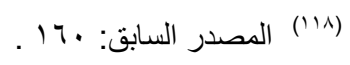

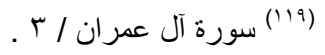

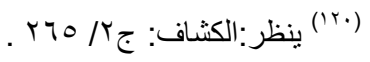

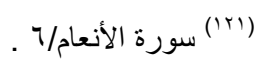

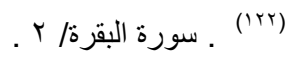

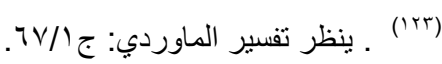

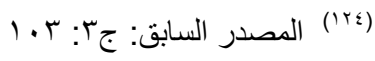

$$
\begin{aligned}
& \text { سورة الأنعام/ ro) (ro) }
\end{aligned}
$$

\section{المصادر والمراجع}

ـ القرآن الكريم

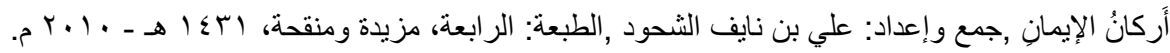

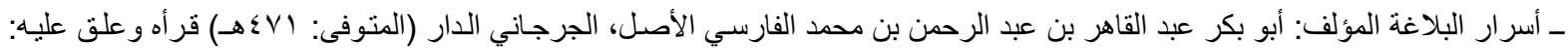

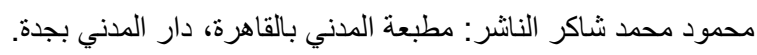
ـــــإعانة المستفيد بشرح كتاب التوحيد, المؤلف : صـالح بن فوزان بن عبد الله الفوزان الناشر :مؤسسـة الرسالة ,الطبعة : الطبعة الثالثة،

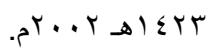
ـ الإيضاح في علوم البلاغة لمؤلف: محمد بن عبد الرحمن بن عمر، أبو المعالي، جلال الدين القزويني الثنافعي، المعروف بخطيب دمثق

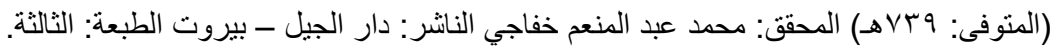

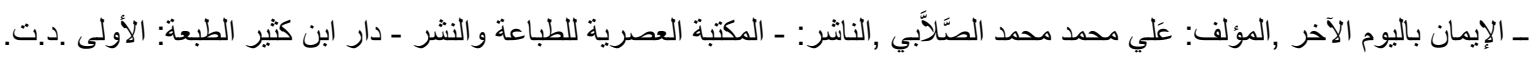

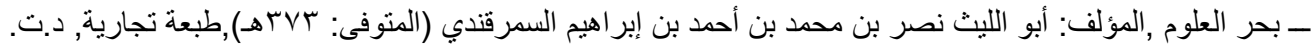

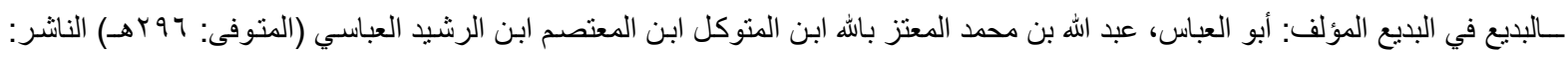

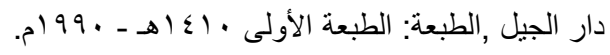

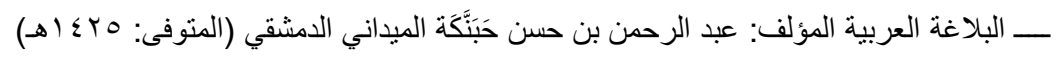

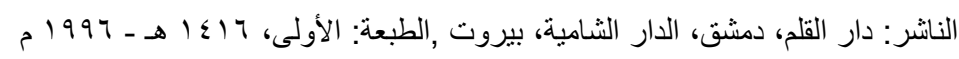

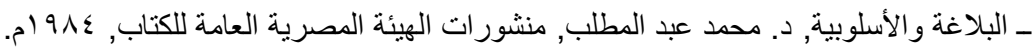

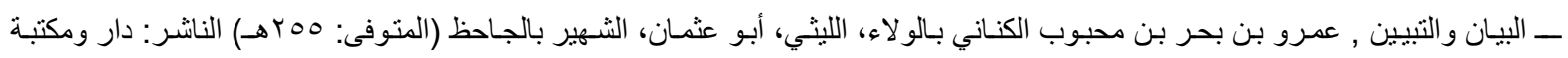

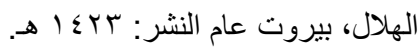

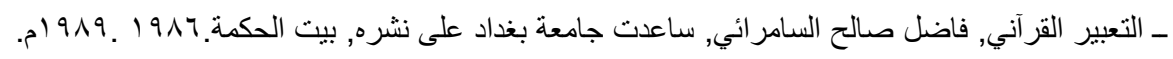

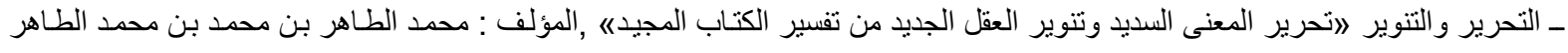

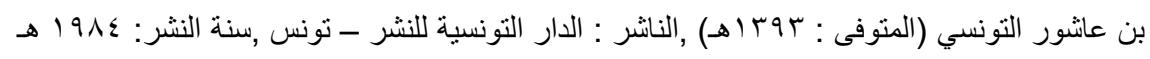

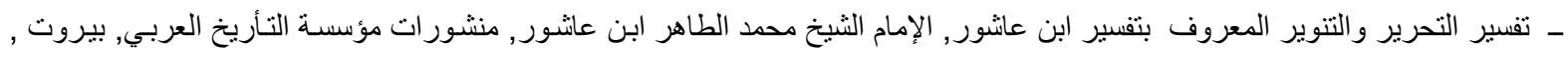

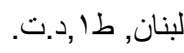

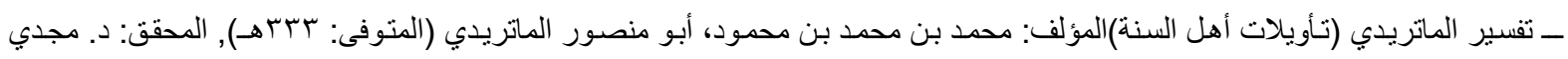

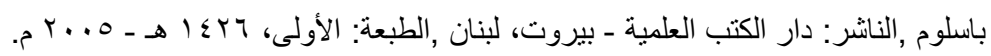

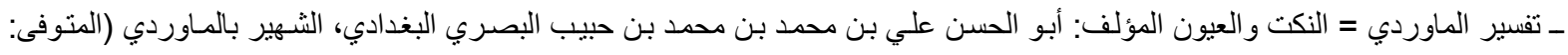

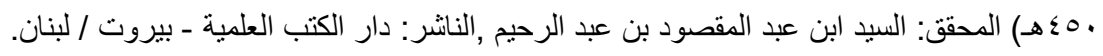

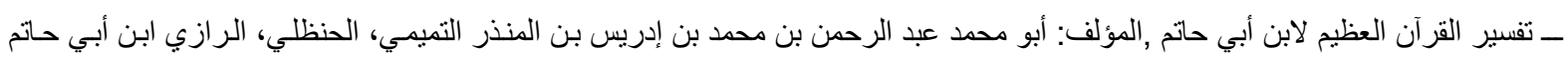

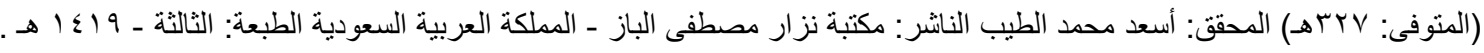

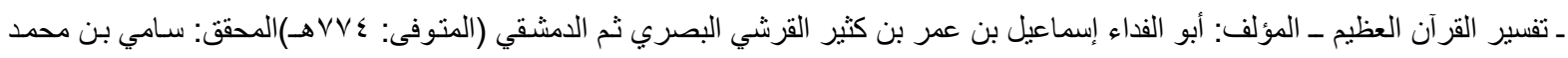

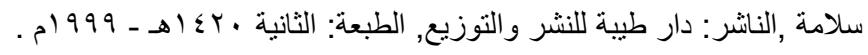

\section{$-r \varepsilon-$}


ــ تفسير المر اغي , المؤلف: أحمد بن مصطفى المر اغي (المتوفى: اVI اهـ) ,الناشـر: شركة مكتبة, ومطبعة مصطفى البابي الحلبي وأولاده

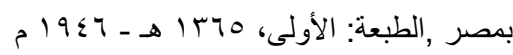

ــ تفسير مقاتل بن سليمان , المؤلف: أبو الحسن مقاتل بن سليمان بن بشير الأزدي البلخي (المتوفى: • 10 هـ) المحقق: عبد الله محمود شحاته

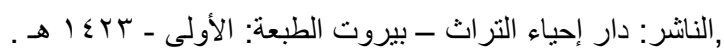

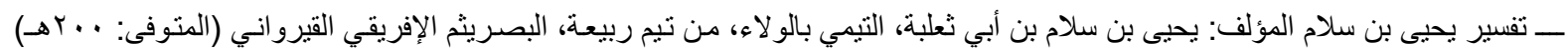

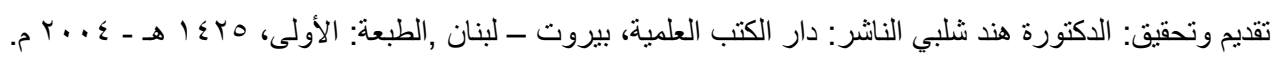

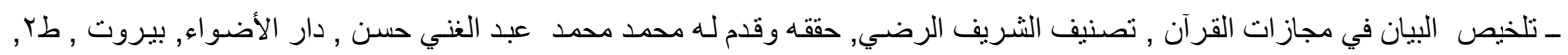
. $1917+1 \leq \cdot 1$

ـ التوسل في كتاب الله عز وجل , المؤلف: طـلال بن مصطفى عرقسوس ,الناثر : الجامعة الإسـلامية بالمدينـة المنورة ,الطبعة: السنة السادسـة

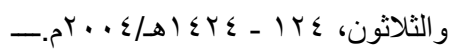

ـ ألجامع الكبير في صناعة المنظوم من الكلام والمنثور , نصر الله بن محمد بن محمد بن عبد الكريم الثيباني، الجزري، أبو الفتح، ضياء الدين،

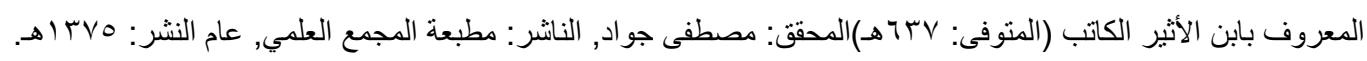

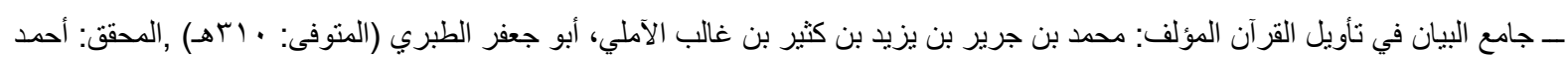

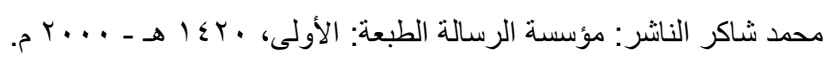

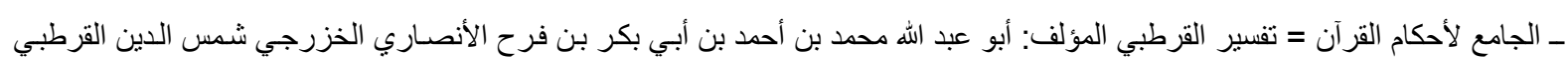

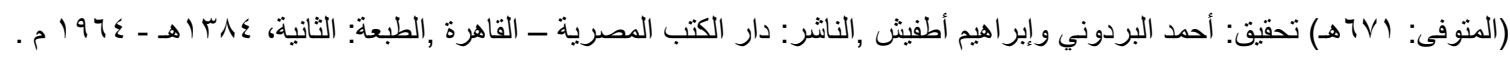

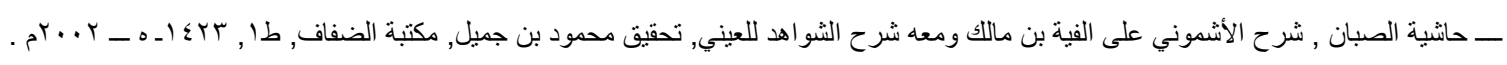
ـ خصائص التر اكيب دارسة تحليلية لمسائل علم المعاني ,المؤلف: محمد محمد أبو موسى ,الناشر : مكتبة وهبة ,الطبعة: السابعة ـ د. د. ت.

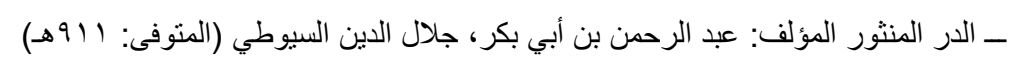

$$
\text { الناشر: دار الفكر - بيروت . }
$$

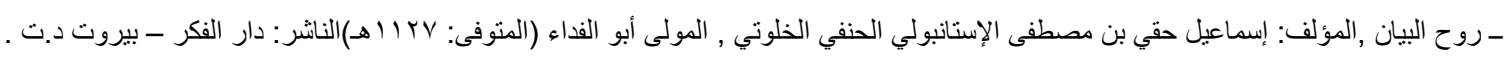

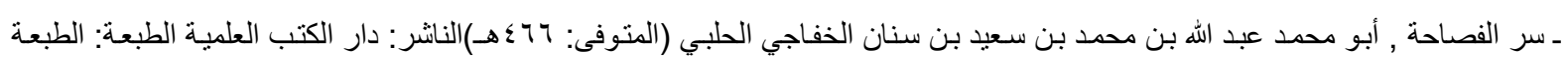

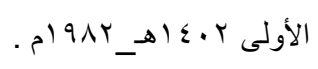

ــــرح التسهيل , تسهيل الفو ائد وتكميل المقاصد, جمال الدين بن عبد الله ابن مالك الطائي الاندلسي, تحقيق: محمد عبد القادر عطا فتحي

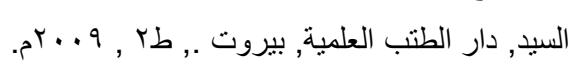

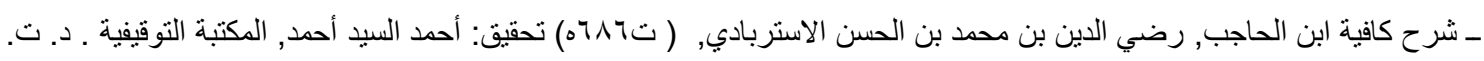
ــ شرح المفصل في النحو , موفق الدين بن يعيش, منشور ات عالم الكتب ـ د. ت. ت.

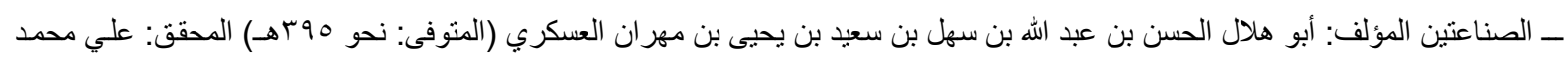

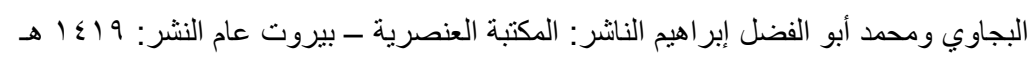

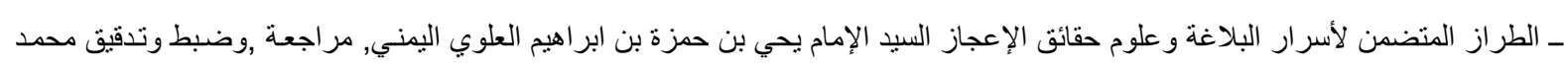

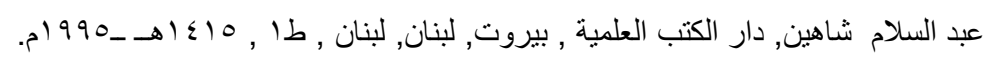

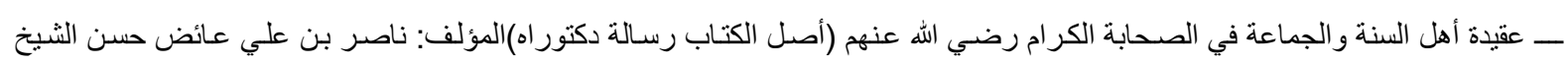

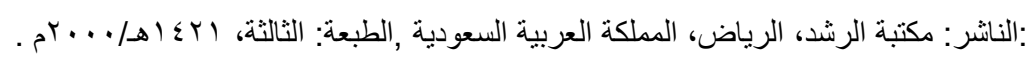

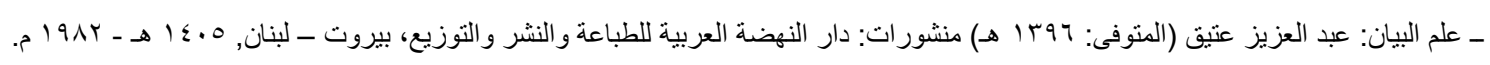

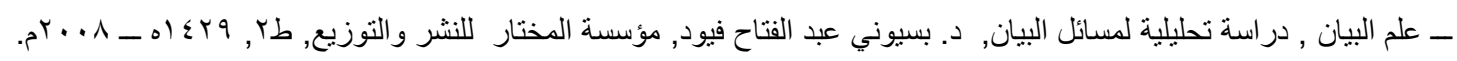

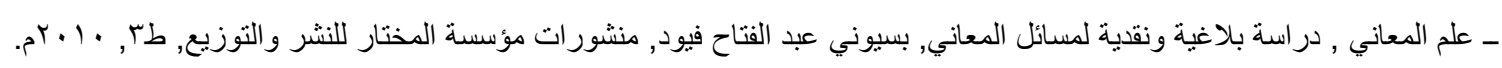

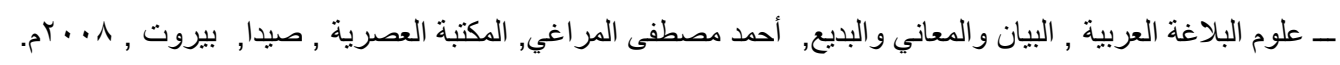

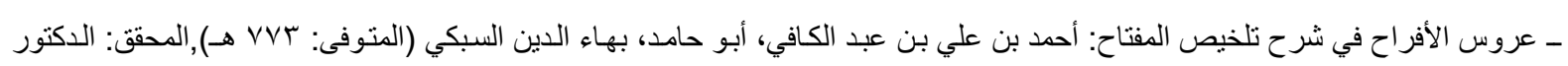

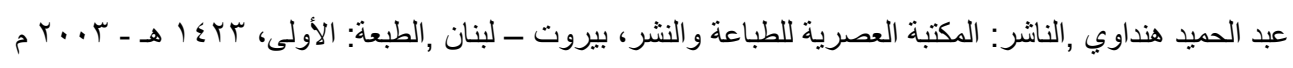


ــ القيامة الكبرى ,المؤلف: عمر بن سليمان بن عبد الله الأشقر العتيبي ,الناشر: دار النفائس للنشر و التوزيع، الأردن ,الطبعة: السادسة، 10 إ هـ 1990

ـ علوم البلاغة لالبديع و البيان و المعاني,: الدكتور محمد أحمد قاسم، الدكتور محيي الدين ديب ,الناشـر: المؤسسـة الحديثة للكتاب، طر ابلس ـ

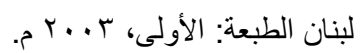

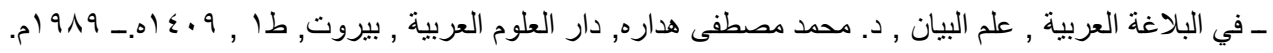

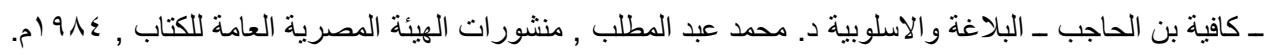

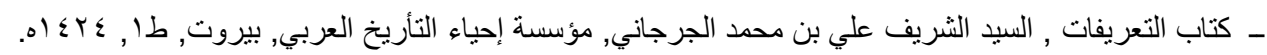

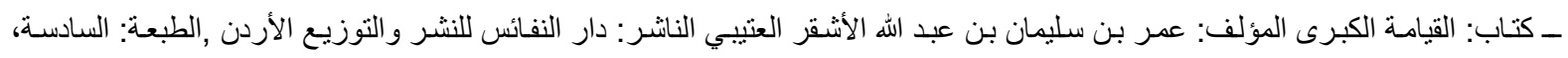
. 1990 ـ 1910 ـــ الكثـاف عن حقائق غوامض التنزيل ,المؤلف: أبو القاسم محمود بن عمرو بن أحمد، الزمخشري جـار الله (المتوفى: ^بهـهـ)الناشر: دار

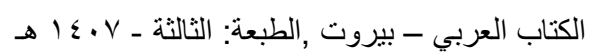

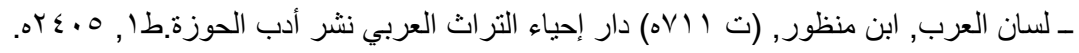

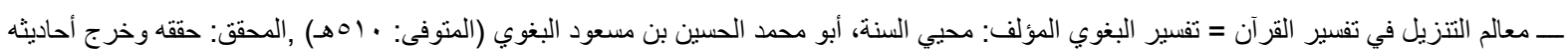

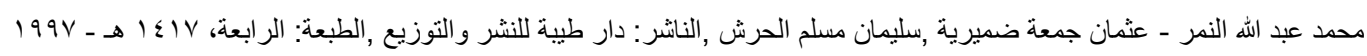

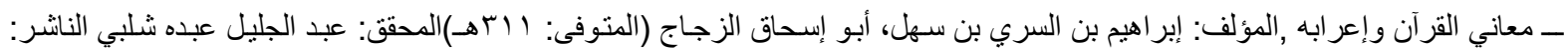

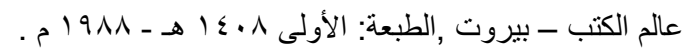
ـ مفاتيح الغيب = التفسير الكبير ,المؤلف: أبو عبد الله محمد بن عمر بن الحسن بن الحسين التيمي الرازي الملقب بفذر الدين الرازي ,خطيب

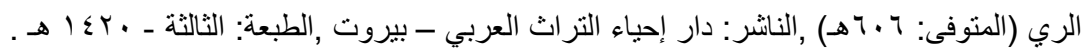

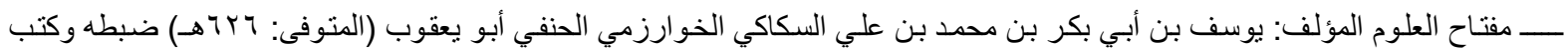

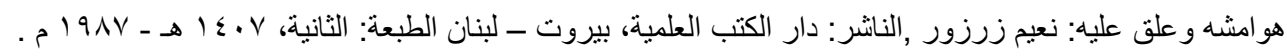

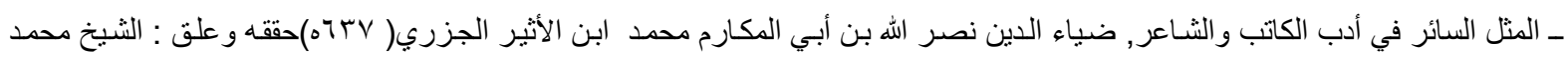
محمد عويضه منشور ات محمد علي بيضون, دار الكتب العلمية, بيروت, لبنان,طا, 991 ام.

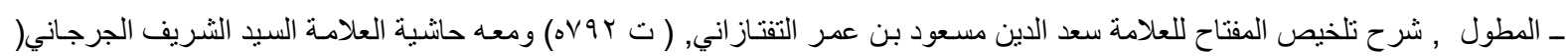

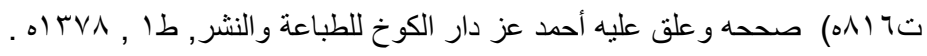

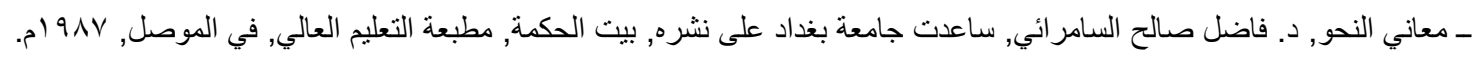

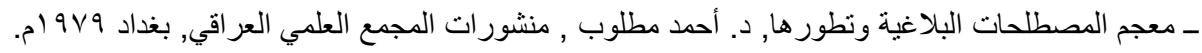
ـ المنهاج الواضح للبلاغة, المؤلف: حامد عونى ,الناشر: المكتبة الأزهرية للتراث, د.ت د.ت.

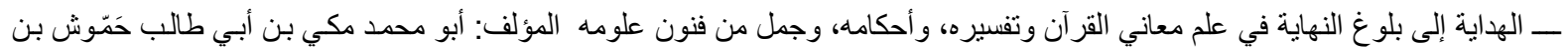

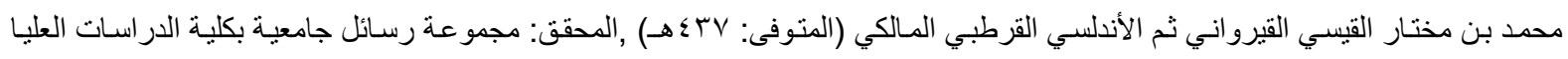
و البحث العلمي- جامعة الثارقة، بإشر اف أ. د: الثاهد البوشيخي ,الناشر: مجموعة بحوث الكتاب و السنة ـ كلية الثريعة و الدراسـات الإسـلامية ـ

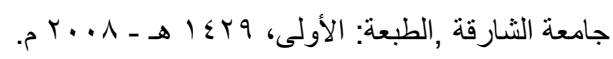
- الرسائل الجامعية ـ لتعريف و التنكير بين النحويين و البلاغيين, دراسة دلالية وظيفية( نمـاذج من السور المكية)( رسـالة ماجستير), إعداد ,الطالبة: نوح عطا الله

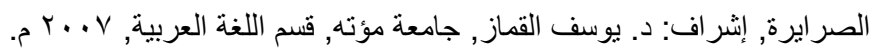

